Florida State University College of Law

Scholarship Repository

Scholarly Publications

2016

\title{
Emerging Legal and Institutional Responses to Sea-Level Rise in Florida and Beyond
}

David L. Markell

Florida State University College of Law

Follow this and additional works at: https://ir.law.fsu.edu/articles

Part of the Environmental Law Commons, and the State and Local Government Law Commons

\section{Recommended Citation}

David L. Markell, Emerging Legal and Institutional Responses to Sea-Level Rise in Florida and Beyond, 42 COLUM. J. ENVTL. L. 1 (2016),

Available at: https://ir.law.fsu.edu/articles/602

This Article is brought to you for free and open access by Scholarship Repository. It has been accepted for inclusion in Scholarly Publications by an authorized administrator of Scholarship Repository. For more information, please contact efarrell@law.fsu.edu. 


\title{
Emerging Legal and Institutional Responses to Sea-Level Rise in Florida and Beyond
}

\author{
David L. Markell*
}

I. Introduction

II. Adaptation Action Areas-Empowering Local Governments to Consider Sea-Level Rise in Comprehensive Plans (2011)

A. Overview ...................................................................... 6

1. Comprehensive Planning in Florida .................................. 6

2. Adaptation Action Areas ................................................ 8

B. Implementation to Date .............................................. 9

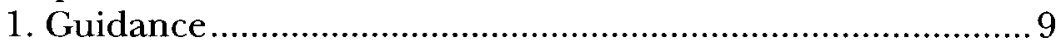

2. Early Efforts to Designate AAAs...................................... 15

III. SB 1094 (2015): Peril of Flood ..................................... 18

A. Timing .................................................................... 19

B. "Inevitability" of Local Government Review ........................ 20

C. Relevant and Appropriate Data.......................................... 23

D. Relevant Time Frame for Assessing Risk ........................... 25

E. The Content of Local Plans ......................................... 26

F. State Review ...................................................... 29

IV. The Southeast Florida Regional Climate Change Compact ..... 31

A. Origins ............................................................. 32

* David L. Markell, Steven M. Goldstein Professor, Florida State University College of Law. Several individuals provided very helpful insights in connection with this Article, including Vicki Arroyo, Janet Bowman, Michael Burger, Ana Bingham, William H. Butler, Barbara Cosens, Ray Eubanks, Michael Gerrard, Nancy Gassman, Jessica Grannis, Gillian Metzger, David L. Powell, Sean Allen Reiss, J.B. Ruhl, Erin Ryan, Thomas Ruppert, Hannah Wiseman, and Katrina Wyman. Stephanie Schwarz (FSU Law 2016) and Lauren Thompson (FSU Law 2017), as well as Barbara Kaplan and Katie Miller, Florida State University College of Law Research Center, provided very helpful research assistance. David L. Powell deserves special thanks for reviewing with me the nuances of Florida land use law. The Article benefited greatly from opportunities to discuss the issues covered in the Article during a workshop at Columbia Law School in the fall of 2015, while I served as the David Sive Visiting Scholar with Columbia's Sabin Center for Climate Change Law, and during a visit with Vicki Arroyo, Jessica Grannis, and others at the Georgetown Climate Center. 


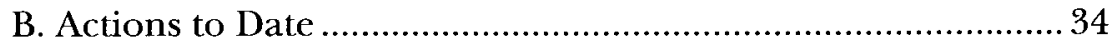

1. Unified Sea-Level Rise Projections (2011 and 2015) ............ 34

2. Vulnerability Assessment (2012) ............................................ 38

3. Regional Climate Action Plan and Implementation

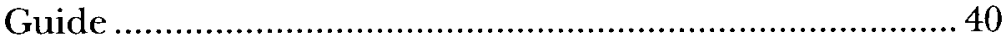

4. Collaborations on Legislative Policy...................................... 41

V. Florida's Reforms and Innovations in Context........................... 42

A. The Key Actors ......................................................................... 43

B. "Adaptive Governance" and "Adaptive Management" ............ 49

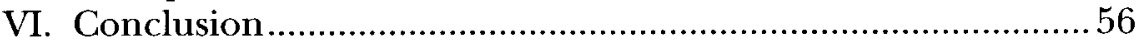

\section{INTRODUCTION}

The legal environment for local government in Florida (the "State") is beginning to change when it comes to sea-level rise ("SLR"). Innovations in institutional structure and governance strategies are underway in the State as well. ${ }^{3}$ This Article reviews three recent developments, which relate primarily to comprehensive planning in the State, and explores their

1. See FlA. STAT. § 163.3164(29) (2016) (defining local government to mean "any county or municipality").

2. Change is occurring in other states' legal regimes as well. See Vicki Arroyo \& Terri Gruce, State and Local Adaptation, in THE LAW OF ADAPTATION TO CLIMATE CHANGE: U.S. AND INTERNATIONAL ASPECTS 569 (Michael B. Gerrard \& Katrina Fischer Kuh eds., 2012) (reviewing state adaptation activities); Aaron D. Ray \& Jessica Grannis, From Planning to Action: Implementation of State Climate Change Adaptation Plans, 3 MiCH. J. SUSTAINABILITY 5, 6 (2015) (noting that, as of October 2014, fourteen states had developed state-led adaptation plans, and eight other states and the District of Columbia had such planning underway). For a summary of federal agency adaptation planning, see HANNAH CONNERS ET AL., U.S. ARMY CORPS OF ENG'RS, REPORT PROVIDING COMPARISON OF ADAPTATION PLANS SUBMITTED TO THE WHIITE HOUSE IN 2014 (2015).

3. See infra Part V (discussing institutional structure innovations in Florida); see also INST. FOR SUSTAINABLE CMTYS., 2014 MUNICIPAL IMPLEMENTATION SURVEy REPORT 4 (2015) [hereinafter Survey Report]; Thomas Ruppert \& AleXander Stewart, SUmmary and

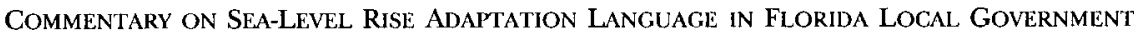
Comprehensive Plans and Ordinances (forthcoming), https://www.flseagrant.org/wpcontent/uploads/Ruppert-Updated-Sea-Level-Language_7.2.15.pdf [https://perma.cc/ TP9D-JUPG] (discussing local government initiatives in Florida regarding SLR); William H. Butler et al., Low-Regrets Incrementalism: Land Use Planning Adaplation to Accelerating Sea Level Rise in Florida's Coastal Communities, 36 J. Plan. Educ. \& RES. 319 (2016) (discussing local government strategies to adapt to SLR); SYDNEY MENEEs \& JeSSICA GRANNIS, CASE STUdies IN Regional Collaboration on adaptation: The Southeast florida Climate Change COMPACT (forthcoming) [hereinafter GCC CASE STUDIES]. 
implications for Florida's local governments, among others. It begins, in Part II, with the State's decision, in 2011 legislation, to give local governments a new, optional tool-referred to as "Adaptation Action Areas" ("AAAs") - to address sea-level rise and related issues in local comprehensive plans. ${ }^{4}$ Part III turns to a second piece of Florida legislation, the State's 2015 "Peril of Flood" legislation, which mandates that local governments begin to address sea-level rise and other causes of flood-related risks through their comprehensive planning processes. ${ }^{5}$ Part IV discusses a third initiative, the Southeast Florida Regional Climate Change Compact, launched in 2009 by four Southeast Florida countiesMiami-Dade, Broward, Palm Beach, and Monroe-to foster local government and regional coordination on sea-level rise and other climate change issues. ${ }^{6}$

Part $\mathrm{V}$ builds on the review in Parts II-IV of these three developments by exploring them through two different lenses. It reviews how these developments may affect the roles of different actors in addressing challenges associated with sea-level rise. ${ }^{7}$ This author and Professor Robert Glicksman have recently highlighted the importance of considering the roles of the entire suite of potential actors as part of policy design. ${ }^{8}$ This Article's review of

4. FLA. STAT. $\$ 163.3177(6)(\mathrm{g})(10)$; see infra Part II. For an overview of Florida's efforts prior to the 2011 legislation, see Erin L. Deady \& Thomas Ruppert, The Link Between Future Flood Risk and Comprehensive Planning, FlA. BAR Ass'N ENVTL. \& LAND UsE L. SEC. ReP., Sept. 2015, at 7, 7-8.

5. FLA. STAT. $\$ 163.3178(2)$ (f); see infra Part III.

6. See infra Part IV. As discussed below, in addition to local government and regional actors, state and federal officials and non-governmental organizations have participated actively in the initiative as well.

7. See infra Part V.

8. David L. Markell \& Robert L. Glicksman, Dynamic Governance in Theony and Applicalion, Pant I, 58 ARIz. L. REV. 563 (2016); see also William W. Buzbee, Urban Sprawl, Federalism, and the Problem of Institutional Complexily, 68 FordHAM L. REV. 57, 94 (1999) (discussing how actors' roles shift over time to address policy challenges).

For examples of the extensive literature concerning the appropriate distribution of responsibility among government actors, see, for example, Arroyo \& Cruce, supra note 2 (identifying challenges in assuring adequate capacity for subnational actors and a "lack of clarity" over federal and state roles); Ann E. Carlson, Iterative Federalism and Climate Change, 103 Nw. U. L. REV. 1097 (2009) (calling for “iterative federalism” governance); Brian C. Chaffin et al., A Decade of Adaplive Governance Scholarship: Synthesis and Future Directions, 19 ECOLOGY \& SOC'Y 56 (2014); Alice Kaswan, Climate Adaplation and Land Use Governance: The Vertical Axis, 39 Colum. J. ENVTL. L. 390, 395-96, 436 (2014) (suggesting “[a] multilevel governance approach that integrates jurisdictional levels could retain the benefits of local control while providing key advantages associated with larger jurisdictional levels," rather than locally-run governance); Kirsten H. Engel, Policy Innovation Under Dynamic, Adapive 
the roles of different actors in the three Florida initiatives identifies and explores some of the outstanding questions concerning these initiatives when viewed through this frame. In addition, the question of how to structure and administer governance approaches, especially in times of dynamic change, is of critical importance in connection with SLR, ${ }^{9}$ and Part V uses the frames of adaptive governance and adaptive management to explore the Florida experience.

This Article's review of these three Florida developments provides an in-depth starting point for understanding key features of the emerging legal and institutional landscape in Florida for addressing sea-level rise, especially with respect to comprehensive planning. ${ }^{10}$ More broadly, several scholars have recently asserted

Federalism and Democralic Experimentalism Compared: Lessons for Federalism and Climate Change Adaptation Policy (Ariz. Legal Studies Discussion Paper No. 16-01, 2016) (discussing democratic experimentalism as a "theory of governance intended to encourage continuous improvement in the problem-solving capabilities of local governing units in a federal or decentralized system of government") (citing Benjamin J. Beaton, Walking the Federalist Tightrope: A National Policy of State Experimentation for Health Information Technology, 108 Colum. L. REV. 1670, 1700-01 (2008)).

Discussions about institutional reform in light of climate change challenges is part of a lively ongoing debate about the appropriate shape of such reform more generally. For example, regarding the concept of federalism, including "classical," "dynamic," and "adaptive federalism," see David E. Adelman \& Kirsten H. Engel, Adaptive Federalism: The Case Against Reallocating Environmental Regulatory Authority, 92 MINN. L. REv. 1796 (2008). Regarding the role for local governments, see David J. Barron, A Localist Critique of the New Federalism, 51 DukE L.J. 377, 382, 432-33 (2001) (considering how central governments can protect local power and in particular suggesting that "there is a growing recognition that the role of central government should not be to supplant local decision making so much as to encourage local jurisdictions to understand their role as components of a larger coordinated system that benefits from cooperative interlocal behavior," and stating that "the important ground of inquiry [in localism as well as in federalism theory] concerns how background rules of central law may be adjusted to foster and promote beneficial interlocal cooperation"); Richard Briffault, Our Localism: Part I-The Siructure of Local Government Law, 90 Colum. L. REv. 1, 1, 6 (1990) (urging "greater attention to the state as a political and legal focal point in the system of local governments" and discussing strong local governments-_-"localism"-as a "value... deeply embedded in the American legal and political culture"); Nestor M. Davidson, Cooperative Localism: Federal-Local Collaboration in an Era of State Sovereignty, 93 VA. L. REV. 959, 960 (2007) (focusing on "cooperative localism," which Davidson characterizes as "direct relations between the federal government and local governments").

9. Markell \& Glicksman, supra note 8, at 565 (reviewing how such challenges exist in other policy arenas as well).

10. Comprehensive planning is likely to be an important tool, but only one among many. See, e.g., John R. NOlon, Protecting the Environment Through Land Use Law: STANDING GROUND 221 (2014) (noting that local legal authority to "determine what type of development may be built within their jurisdictions, including disaster-prone areas and 
that current legal regimes and institutional arrangements will require significant reform because of the stresses associated with climate change, ${ }^{11}$ and this effort to review and analyze ongoing developments in legal regimes and institutional structures contributes to the still-nascent, but rapidly expanding, literature that explores the implications of climate change for environmental and other legal regimes. ${ }^{12}$

vulnerable coastal areas... is found in state constitutions, planning enabling acts, zoning enabling acts, home rule authority, and additional state laws that permit localities to protect health and safety, to preserve the local physical environment, and to mitigate disaster damage"); Alice Kaswan, supra note 8, at 393, 403-07 (discussing the important role of land use law in climate change adaptation, but also noting that many other areas of law will be implicated, such as natural resources law, public health law, housing law, energy law, and immigration law); J.B. Ruhl, Climate Change Adaplation and the Structural Transformation of Environmental Law, 40 ENVTL. L. 363, 377-79, 391-416 (2010) (describing how adaptation efforts are likely to implicate many areas of law).

11. J.B. Ruhl, General Design Principles for Resilience and Adaptive Capacity in Legal SystemsWith Applications to Climate Change Adaptation, 89 N.C. L. REV. 1373, 1374 (2011) (suggesting that "[d]emands on the legal system will be intense and long term"); Ruhl, supra note 10, at 376-77 (suggesting that climate change is likely to effect a "structural transformation" of the field of environmental law because of the pressures it will generate and that climate change will "exert tremendous structural pressures on the very design and implementation of the law itself"). For similar assessments, see, for example, Kaswan, supra note 8, at 392 (concluding that "the scale of anticipated climate change poses profound challenges to existing governance norms," including the "norm of local control over land use"); Ray \& Grannis, supra note 2, at 5 (noting that "the impacts of climate change are now challenging and will continue to challenge public institutions at all levels of government"). Scholarship in other disciplines has sounded the same warning. See, e.g., Butler et al., supra note 3, at 319 (noting that "climate change poses immense challenges to conventional land use planning practice").

12. See Nolon, supra note 10 , at 221 (noting that a significant challenge is "how to integrate land use decision making - a role generally assigned to local governments under our federal system-with state and federal environmental initiatives"); Daniel A. Farber, Climate Adaptation and Federalism: Mapping the Issues, 1 SAN DIEGO J. CliMATE \& ENERGY L. 259, 259-60 (2009) (stating that "[t]here has been little if any discussion... about the appropriate roles of the states and the federal government in adapting to climate change" and characterizing his article as a "first step in mapping this new terrain"); Kaswan, supra note 8, at 395-96 (noting that "only a few have addressed federalism and adaptation"); J. B. Ruhl \& James Salzman, Climate Change Meels the Law of the Horse, 62 DukE L.J. 975, 980 (2013) (noting that the debate surrounding climate policy has recently begun to focus on adaptation and that "a flood of recent scholarship has focused on the implications of climate adaptation for the law"). Work to catalogue and analyze state-level initiatives is at an early stage. See, e.g., Ray \& Grannis, supra note 2, at 6, 21, 22 (describing their article as an "early attempt" to assess state progress; noting that scholarly inquiry into state adaptation planning is in its early stages; and identifying a need for scholars to research adoption and implementation of local adaptation plans and the actions of regional collaborations including the Southeast Florida Climate Change Compact); Butler et al., supra note 3, at 326-28 (similarly noting that the literature concerning efforts to understand and assess adaptation activity is in its infancy). For examples of such work, see, for example, CARMIN ET 


\section{ADAPTATION ACTION AREAS-EMPOWERING LOCAL GOVERNMENTS TO CONSIDER SEA-LEVEL RISE IN COMPREHENSIVE PLANS (2011)}

\section{A. Overview}

\section{Comprehensive Planning in Florida}

Comprehensive plans occupy an important place in the legal landscape governing land use in Florida. State law requires each local government to adopt such a plan. ${ }^{13}$ Other land use decisions by a local government, such as the issuance of land development regulations and development orders, must be consistent with the comprehensive plan. ${ }^{14}$ As a result, such plans have been "likened

al., Progress and Challenges in Urban Climate adaptation Planning: Results of a GLObal SURVEY (2012); GCC CASE STUdies, supra note 3; Arroyo \& Cruce, supra note 2; Butler et al., supra note 3, at 322-23 (identifying several studies in addition to reviewing their own); RUPPERT \& STEWART, supra note 3 (reviewing local government efforts in Florida); Ira Feldman \& Joshua H. Kahan, Preparing for the Day After Tomorrow: Frameworks for Climate Change Adaplation, 8 SUSTAINABle DEv. L. \& POL'Y 61 (2007). There has been a historic lack of attention to adaptation well beyond the legal scholarship, in part because of the preoccupation with mitigation issues, but that has changed in recent years. See U.S. Gov'T accountability Office, GaO-10-113, Climate Change Adaptation: Strategic Federal. Pilanning Could Help Government Officlals Make More Informed Decisions, at 2 (2009) (noting that climate change adaptation "has begun to receive more attention" even though past federal government attention had focused on mitigation). This Article does not address the normative debates about how society should manage the "harms" and "benefits" of climate change. Instead, as the text reflects, this Article's focus is on the legal regime and institutional shifts that are occurring in Florida in response to increased state and local concern about sea-level rise and flood risk.

13. Fla. Stat. $\$ 163.3167(2)$ (2016); see also John DeGrove, Planning Policy And POLITICS: SMART GROWTH AND THE STATES 47-48 (2005) (noting that each local government had developed a comprehensive plan by the late 1970s). Comprehensive plans are only one of many planning efforts. Butler et al., supra note 3 .

14. FLA. STAT. $\$ 163.3161(6)$ (providing that "no public or private development shall be permitted except in conformity with comprehensive plans"); id. $\S 163.3194$ (1)(a), (b) (providing that, once a local government has adopted a comprehensive plan, "all development undertaken by, and all actions taken in regard to development orders by, governmental agencies in regard to land covered by such plan" must be consistent with that plan.); id. $\S 163.3167(5)$ (creating a narrow exception for projects with vested rights); id. $\S$ 163.3177 (1) (providing that a comprehensive plan is to "provide the principles, guidelines, standards, and strategies for the orderly and balanced future economic, social, physical, environmental, and fiscal development of the area," and to "establish meaningful and predictable standards for the use and development of land and provide meaningful guidelines for the content of more detailed land development and use regulations"). 
to a constitution for all future development within the governmental boundary." 15

State law requires that local governments' comprehensive plans include several "mandatory elements." 16 These include elements for capital improvements; ${ }^{17}$ future land use; ${ }^{18}$ transportation; ${ }^{19}$ general sanitary sewer, solid waste, drainage, potable water, and natural groundwater aquifer recharge $;{ }^{20}$ conservation; ${ }^{21}$ recreation and open space; $;^{22}$ housing; ${ }^{23}$ and intergovernmental coordination. ${ }^{24}$ Units of local government "abutting the Gulf of Mexico or the Atlantic Ocean, or which include or are contiguous to waters of the state where [certain] marine species of vegetation" exist, must also include a "coastal management element." ${ }^{25}$ The purpose of the coastal management element is to "guide the local government's decisions and program implementation" in "[m]aintain [ing], restor[ing], and enhanc[ing] the overall quality of the coastal zone environment." 26

15. Machado v. Musgrove, 519 So. 2d 629, 632 (Fla. Dist. Ct. App. 1987) (citing O'Loane v. O'Rourke, 42 Cal. Rptr. 283, 288 (Ct. App. 1965)).

16. FLA. STAT. $\S 163.3177$ (1)(a). State law also imposes other requirements for comprehensive plans and it allows local governments to include various optional elements such as economic development, historic preservation, or community design. Id. $\S$ 163.3177(1)(a). Several local governments in Florida have added an optional "climate change" element, including Broward County, which won a National Planning Award from the American Planning Association for developing the first climate change element in Florida. E-mail from Nancy J. Gassman, Assistant Pub. Works Dir., Sustainability Div., City of Fort Lauderdale, to author (Dec. 29, 2015) (on file with author).

17. FLA. STAT. $\$ 163.3177$ (3) (a).

18. Id. $\$ 163.3177(6)(\mathrm{a})$.

19. Id. $\S 163.3177(6)$ (b).

20. Id. $\$ 163.3177(6)(\mathrm{c})$.

21. Id. $\$ 163.3177(6)(\mathrm{d})$.

22. Id. $\$ 163.3177(6)(\mathrm{e})$.

23. Id. $\$ 163.3177(6)(f)$.

24. Id. $\S 163.3177(6)(\mathrm{h})$.

25. Id. $\$ \S 380.24,163.3177(6)(\mathrm{g})$. The coastal management element must be "appropriately related" to the requirements in sections $163.3177(6)(d)$ and (e), the conservation element of the comprehensive plan and the recreation and open space element, respectively. The coastal management element must also meet the requirements of sections $163.3178(2)$ and (3), which require that the element be based on "studies, surveys, and data; be consistent with coastal resource plans prepared and adopted pursuant to general or special law"; and contain a series of analyses, including "principles for hazard mitigation and protection of human life against the effects of natural disaster." Id. $\S$ $163.3178(2)$.

26. Id. $\$ 163.3177(6)(\mathrm{g})(1)$. The statute lists several other objectives as well, most of which are complementary. They include: 


\section{Adaptation Action Areas}

An amendment to State law adopted in 2011 empowers local governments to include a new feature in the coastal management element of their comprehensive plans. ${ }^{27}$ The amendment allows local governments to designate as "Adaptation Action Areas" ("AAAs") low-lying coastal zones that are experiencing flooding and are vulnerable to sea-level rise: "At the option of the local government, develop an adaptation action area designation for those low-lying coastal zones that are experiencing coastal flooding due to extreme high tides and storm surge and are vulnerable to the impacts of rising sea level." ${ }^{28}$ As the statutory text makes clear, the 2011 amendment allows local governments to designate Adaptation Action Areas at their option; it does not require them to do so.

2. Preserve the continued existence of viable populations of all species of wildlife and marine life.

3. Protect the orderly and balanced utilization and preservation, consistent with sound conservation principles, of all living and nonliving coastal zone resources.

4. Avoid irreversible and irretrievable loss of coastal zone resources.

5. Use ecological planning principles and assumptions in the determination of the suitability of permitted development.

6. Limit public expenditures that subsidize development in coastal high-hazard areas.

7. Protect human life against the effects of natural disasters.

8. Direct the orderly development, maintenance, and use of ports identified ... to facilitate deepwater commercial navigation and other related activities.

9. Preserve historic and archaeological resources, which include the sensitive adaptive use of these resources.

Id. $\$ 163.3177(6)(\mathrm{g})$.

27. The Southeast Florida Regional Climate Change Compact advocated for the State to incorporate the concept of AAAs into legislation. E-mail from Nancy J. Gassman to author, supra note 16; see also SE. Fla. Reg'l COMPACt CTYS., Regional Climate Action Framework: Implementation Guide (2014). This Article does not address whether local governments could have developed AAAs prior to the 2011 legislation. See Robert M. Rhodes, The 2011 Community Planning Act: Cerlain Change, Uncertain Reform, 34 ENVTL. \& LAND USE L. SEC. REP., June 2013, at 1, 1 ("The [2011 legislation] has been praised as overdue reform that simplifies a complex intergovernmental program and returns major planning responsibility and accountability to local government. It has also been excoriated as a wholesale retreat from sound planning practice that cuts the heart out of an effective program that didn't require major surgery."). It is not the purpose of this Article to "re-fight the battles over enactment of the 2011 revisions," as Rhodes put it. Id.

28. FLA. STAT. $\$ 163.3177(6)(\mathrm{g})(10)$; see also id. $\$ 163.3164(1)$ (defining an Adaptation Action Area as a "designation in the coastal management element of a local government's comprehensive plan which identifies one or more areas that experience coastal flooding due to extreme high tides and storm surge, and that are vulnerable to the related impacts of rising sea levels for the purpose of prioritizing funding for infrastructure needs and adaptation planning"). 
The legislature indicated that it was enabling local governments to designate one or more AAAs to facilitate their efforts to promote resilience to coastal flooding caused by sea-level rise and other events: "Local governments that adopt an adaptation action area may consider policies within the coastal management element to improve resilience to coastal flooding resulting from high-tide events, storm surge, flash floods, stormwater runoff, and related impacts of sea-level rise." ${ }^{29}$ The 2011 amendment includes possible criteria a local government might use to designate AAAs but ultimately empowers local governments to devise their own: "Criteria for the adaptation action area may include, but need not be limited to, areas for which the land elevations are below, at, or near mean higher high water, which have a hydrologic connection to coastal waters, or which are designated as evacuation zones for storm surge." ${ }^{30}$ In the definition of AAAs, the State explains that a local government might decide to designate an AAA in its comprehensive plan "for the purpose of prioritizing funding for infrastructure needs and adaptation planning." 31 It seems clear that the purpose of the law went beyond facilitating local governments' prioritizing funding; the law was also intended to help local governments attract funding to address flood risks from sea-level rise and other factors. ${ }^{32}$

\section{B. Implementation to Date}

\section{Guidance}

In addition to empowering local governments to designate AAAs in their comprehensive plans, the State has issued guidance to help local governments do so. As part of a five-year State of Florida Department of Economic Opportunity ("DEO") project to integrate sea-level rise adaptation into existing planning mechanisms, DEO contracted with the South Florida Regional Planning Council ("SFRPC") to research AAA implementation strategies and to develop a planning guidebook to help local

29. Id. $\S 163.3177(6)(\mathrm{g})(10)$.

30. Id.

31. Id. $\S 163.3164(1)$.

32. Se. Fla. Reg'l Compagt Ctys., A Region Responds to a Changing Climate: Regional Climate ACtion Plan 14 (2012) [hereinafter RCAP] (suggesting that the Florida statute will "maximize funding opportunities"). 
governments pursue AAAs. ${ }^{33}$ The SFRPC has prepared two documents that relate to AAAs: (1) Adaptation Action Areas: Policy Options for Adapting Planning For Rising Sea Levels (2013); and (2) Adaptation Action Areas: A Planning Guidebook for Florida's Local Governments (2015). ${ }^{34}$ This Article focuses on the 2015 document (the "Guidebook").

The 2015 SFRPC Guidebook is intended to help local communities "understand how they can use Adaptation Action Areas to adapt to coastal flooding." 35 The SFRPG observes that, with the legislature's adoption of AAAs, "[e]ffective strategies are now supported by State Statute to promote and support further adaptation initiatives around Florida." 36 The Guidebook suggests that in recent years Florida communities have undergone a "major paradigm shift," in which they previously focused on post disaster recovery and now increasingly are pursuing "proactive resilience that prevents and mitigates risks." ${ }^{37}$ The SFRPC situates AAAs "within the larger suite of adaptation planning." 38

The SFRPC identifies several key elements in adaptation planning. One involves preparation of a vulnerability assessment. Such an assessment includes an "exposure analysis," which uses one or more projections of sea-level rise to estimate when (if at all) sealevel is expected to rise, and how much it is expected to rise. ${ }^{39}$ Such an analysis "can depict which areas in the community are likely to be susceptible to the chosen sea-level rise scenario on a map." ${ }^{40}$ It also should include an "impact" analysis that identifies key resources that are put at risk by the sea-level rise projected by

33. The DEO is the designated as the "State land planning agency," FLA. STAT. \& 163.3164(43), and Regional Planning Councils are also entities created under State law, id. $\S \S 186.001-.515$. The funding for the project was provided by the National Occanic and Atmospheric Administration and the State Department of Environmental Protection.

34. S. Fla. Reg'l Planning Council, Adaptation Action areas: Policy Options for adapting Planning for Rising Sea Levels, at 1-2 (2013); S. Fla. Reg'l Planning Council, AdAPTATION ACTION AREAS: A PlanNing GUIDEBOOK FOR FloRIDA's LOCAL GOVERNMENTS, at 4 (2015) [hereinafter SFRPC GUIDEBOOK]. The 2013 SFRPC report explains the AAA legislation and offers a "snapshot" of Broward County's related adaptation policies. Broward County and the City of Fort Lauderdale were subcontractors to the SFRPC. E-mail from Nancy J. Gassman to author, supra note 16.

35. SFRPC GUIDEBOOK, supra note 34, at 4.

36. Id.

37. $I d$.

38. Id. at 7

39. Id at 13 .

40. Id. 
the exposure analysis, including human populations, natural resources, and infrastructure. ${ }^{41}$ Assessing adaptive capacities"measur[ing] the degree to which [a community] is equipped to adapt to sea-level rise, through the existence of policies, structures, finances, and human resources that can assist or already are assisting to adapt to potential changes"-is the third component the SFRPC recommends local governments include in a vulnerability assessment. ${ }^{42}$

Following the vulnerability assessment, the SFRPC Guidebook recommends that a community consider a mix of strategies to address its vulnerabilities. Some experts have classified such strategies based on whether the goal is protection, accommodation, or retreat ("PAR"). ${ }^{43}$ As a third recommended step for local

41. $I d$.

42. Id.

43. Id.; NOLON, supra note 10, at 221 (identifying PAR as the "three main policies for dealing with sea level rise"). Some have suggested "avoidance" as a variation of retreat. See Butler et al., supra note 3, at 321. DEO has identified five strategies for adaptation planning:

1. Protection-Protection strategies involve "hard" and "soft" structurally defensive measures to mitigate the impacts of current and future flooding, such as seawalls or beach renourishment, in order to maintain existing development.

2. Accommodation-Accommodation strategies do not act as a barrier to inundation but rather alter the design, construction, and use of structures to handle periodic flooding. Examples include elevating structures and stormwater retrofits that improve drainage or use natural areas to soak up or store water and runoff (i.e., green infrastructure).

3. Strategic Relocation-Strategic relocation involves the possible relocation of existing development to safer areas through voluntary or incentivized measures in populated, hazard prone areas that reduce the intensity of development and/or gradually increase setbacks over time. Such options usually involve the transition of vulnerable land from private to public ownership, but may also include other strategies such as transfer of development rights, purchase of development rights, and rolling easements.

4. Avoidance-Avoidance involves anticipatory actions taken to direct new development away from vulnerable lands to safer areas. Examples include land conservation, conservation easements, transfer of development rights, and increased coastal setbacks.

5. Procedural-Procedural strategies aim to generate vulnerability and adaptation information, increase awareness of vulnerabilities and adaptation options, or incorporate such information into plans or policies. Examples include vulnerability assessments, community outreach and education activities, new comprehensive plan language addressing sea level rise, and real estate disclosures.

Adaptalion Planning-Planning for Coastal Flooding and Sea Level Rise, FLA. DEPT. ECON. OPPORTUNITY, http://www.floridajobs.org/community-planning-and-development/ programs/community-planning-table-of-contents/adaptation-planning [https://perma.cc /KJ2L-39FE] (last visited Oct. 22, 2015); see also VIVIEN GORNITZ, RISING SEAS: PAST, PRESENT, FUTURE 226-38 (2013) (discussing PAR); SFRPC GUIDEBOOK, supra note 34, at 47-50. Butler et al. report that "accommodation predominates" for those communities that have committed to considering or implementing SLR adaptation strategies. Butler et al., supra 
governments, the SFRPC provides a sixteen-piece toolkit for local governments to consider in implementing each of these strategies in the Adaptation Action Areas context. These tools include transferable development rights, zoning and overlay zones, setbacks and buffers, building codes and design, impact fees, conservation easements, real estate disclosures, coastal land acquisition programs, and land trusts. ${ }^{44}$ The SFRPC notes that "[b]ecause the designation of an [AAA] is flexibly written in Florida Statute[s], the benefits the Areas may confer relate to numerous... growth management tools already in existence to protect the welfare of community residents. ${ }^{25}$

Once a community understands its vulnerabilities, strategic options, and the tools available to implement different strategies, the next step the SFRPC identifies is for a community to prioritize the adaptation actions it should take. ${ }^{46}$ The SFRPC recommends that communities use the STAPLEE method to consider the relative costs and benefits of a project based on seven variables:

- Social-What are the socially acceptable adaptation strategies in the community?

- Technical-What are the technically feasible adaptation strategies within the community?

- Administrative-Which adaptation strategies are implementable by community leadership?

- Political-Which adaptation strategies are politically acceptable within the community?

- Legal-Which adaptation strategies are legally implementable by the community under state and municipal law?

- Economic-What are the cost-effective adaptation strategies available to the community?

- Environmental-Which adaptation strategies are most favorable to the environment, as determined by community conservation plans and statewide guidance? ${ }^{47}$

note 3, at 324-26 (summarizing the different strategies local governments have considered or discussed); id. at 326-27 (summarizing the monitoring and evaluation efforts).

44. SFRPG GUIDEBOOK, supra note 34 , at 50. The SFRCP suggests a seventeenth legal instrument, land readjustment strategies, as well. $I d$. at 50,61 .

45. Id. at 73 .

46. Id. at 14 .

47. Id. at 63 . 
The final key step involves implementing the adaptation actions that have been prioritized. This includes identifying and pursuing funding opportunities for the actions; integrating actions into existing plans and activities; creating a schedule for implementation that identifies key actors responsible for different elements; and monitoring and evaluating performance. ${ }^{48}$

How might AAAs fit into a local community's adaptation planning efforts? The SFRPG suggests a four-phased approach. The first phase is to "creat[e] the policy framework within the Coastal Management Element of [the community's] comprehensive plan" by including policy language that "[r] ecognizes the value of ... designat[ing] Adaptation Action Areas to improve the resilience of [the community] to coastal flooding and related impacts of sea-level rise." 49 The second is to identify the criteria the community should consider when identifying areas for possible designation. ${ }^{50}$ These criteria may be those listed in the state statute or others. ${ }^{51}$ The third is to describe the mechanisms the local government should use to create an actual designation. ${ }^{52}$ Finally, the SFRPC encourages local governments to identify potential funding mechanisms that would help to implement the adaptation actions identified. ${ }^{53}$ Beyond these four implementation stages for establishing one or more AAAs and funding implementation, the Guidebook suggests that local governments may find it helpful to align the AAA designation and any projects within the AAA with other comprehensive plan elements, such as the five-year schedule of capital improvements within the "capital improvements" element. Similarly, local governments may want to adopt special policies for coordination in the "intergovernmental coordination" element. ${ }^{54}$ The SFRPC included the following table of nineteen documents that have the potential to address sea-level rise as an Adaptation Action Area

\footnotetext{
48. Id. at $14-15$.

49. $I d$. at 66 .

50. $I d$ at 67 .

51. Id.; see also supra note 30 and accompanying text (listing statutory criteria).

52. SFRPC GUIDEBOOK, sufra note 34 , at 67 . The designation may be through a narrative description of the location on maps in the comprehensive plan; through the capital improvement plan; through adoption of a resolution or an ordinance; or other means. Id. at

53. Id. at 67

54. Id.
} 68. 
checklist. It offers the table as a "management tool whereby community officials may keep track of the assortment of policy documents whose uses intersect along Adaptation Action Area lines." ${ }^{55}$

\section{Table 1}

\begin{tabular}{|c|c|c|}
\hline EXAMPLE DOCUMENTS & $\begin{array}{l}\text { ADOPTION } \\
\text { YEAR }\end{array}$ & $\begin{array}{c}\text { DO INTEGRATION } \\
\text { OPPORTUNITIES } \\
\text { EXIST? }\end{array}$ \\
\hline \multicolumn{3}{|l|}{ Municipal Comprehensive Plan } \\
\hline \multicolumn{3}{|l|}{ All-Hazards Mitigation Plan } \\
\hline \multicolumn{3}{|l|}{ Floodplain Management Plan } \\
\hline \multicolumn{3}{|l|}{ Evacuation Plan } \\
\hline \multicolumn{3}{|l|}{ Emergency Response Plan } \\
\hline \multicolumn{3}{|l|}{ Continuity of Operations Plan } \\
\hline \multicolumn{3}{|l|}{ Disaster Recovery Plan } \\
\hline \multicolumn{3}{|l|}{ Post-Disaster Redevelopment } \\
\hline \multicolumn{3}{|l|}{ Capital Improvements Plan } \\
\hline \multicolumn{3}{|l|}{ Economic Development } \\
\hline \multicolumn{3}{|l|}{ Coastal Plan or Element } \\
\hline \multicolumn{3}{|l|}{ Shoreline Restoration Plan } \\
\hline \multicolumn{3}{|l|}{ Open Space Plan } \\
\hline \multicolumn{3}{|l|}{ Stormwater Management Plan } \\
\hline \multicolumn{3}{|l|}{ Historic Preservation Plan } \\
\hline \multicolumn{3}{|l|}{ Zoning Ordinance } \\
\hline \multicolumn{3}{|l|}{ Flood Damage Prevention } \\
\hline \multicolumn{3}{|l|}{ Subdivision Ordinance } \\
\hline Building Code & & \\
\hline
\end{tabular}

55. Id at 72-73. This table reflects the interrelationship between comprehensive planning and other legal authorities. See also NOLON, supra note 10, at 221. 


\section{Early Efforts to Designate AAAs}

In a July 2015 report, Thomas Ruppert, Florida Sea Grant Coastal Planning Specialist, and Alexander Stewart surveyed Florida local government actions in order to assess efforts to address SLR in local comprehensive plans, including adoption of AAAs. ${ }^{56}$ Ruppert and Stewart identified 195 local governments that were subject to the "coastal management element" requirement, ${ }^{57} 161$ municipalities and thirty-four counties. ${ }^{58}$ The authors were able to obtain and analyze at least the comprehensive plans, and in some cases more than that, for all but seven of the $195 .^{59}$ Of these 188 local governments, twenty-six (14\%) explicitly "mention or address sea-level rise in their comprehensive plans." ${ }^{60}$ Six (3\%) mention AAAs in their comprehensive plans. ${ }^{61}$ Ruppert and Stewart emphasized that language seemingly requiring a local government to do something in connection with SLR is "often not selfexecuting." ${ }^{2}$ As a result, comprehensive plan language may be "more proactive than the tangible actions of a local government in day-to-day operations." ${ }^{33}$ As of November 2015, the number of local governments that had incorporated Adaptation Action Areas language into their comprehensive plans had increased to eight, according to DEO officials. ${ }^{64}$ Of these, according to DEO, two have

56. RUPPERT \& STEWART, supra note 3. During their research, the authors uncovered several local documents beyond comprehensive plans that include sea-level rise, and they discuss those references as well. Id. at 4 .

57. Id. at 41. There are approximately five hundred local governments in Florida, not including special districts. Id. at 3.

58. Id. at 41 .

59. Id.

60. Id. at 39

61. Id. at 5 .

62. Id. at 4 .

63. Id. The authors also acknowledge that they were not able to evaluate the "level of implementation" of each commitment in a comprehensive plan. Id. They found that a few local governments "stand out" for "how carefully they have spelled out what they will do in response to SLR," notably Miami-Dade County, Broward County, and Fort Lauderdale. Id. at 6.

64. E-mail from Sean Allen Reiss, Planning Analyst, Div. of Cmty. Dev., Fla. Dep't of Econ. Opportunity, to author (Nov. 4, 2015) (on file with author) (identifying three counties (Broward, Miami-Dade, and Palm Beach) and five municipalities (Fernandina Beach, Fort Lauderdale, Key West, Village of Pinecrest, and Satellite Beach)); see, e.g., VILL. OF Pinecrest, Comprehensive Development Master Plan ch. 10 (Apr. 14, 2015) (incorporating a new climate change element and identifying and adopting Adaptation Action Areas). The South Florida Regional Planning Council's August 2015 Guidance identifies the City of Punta Gorda, and Levy County working with the Towns of Yankeetown 
an actual physical designation. Satellite Beach has designated its Coastal High Hazard Area as an Adaptation Action Area and is currently working to designate other areas as AAAs as well. ${ }^{65}$ The Village of Pinecrest has also designated an AAA. ${ }^{66}$ As of November 2015, DEO was not aware of much progress in implementing any projects following, and due in part to, an AAA designation. ${ }^{67}$

Based on the Ruppert and Stewart July 2015 survey and the information provided in November 2015 by DEO, it appears that a handful of Florida's 195 local coastal governments have begun the process of including the concept of AAAs in their comprehensive plans since the legislature created AAAs in 2011. The Southeast Florida communities appear to be at the forefront of this effort. Of the eight local governments that DEO identifies as having incorporated AAAs into their comprehensive plans, six are in Southeast Florida (the exceptions are Fernandina Beach, near Jacksonville, and Satellite Beach).

For several reasons, it is too early to project the extent to which local governments will use this new tool available to them under State law. First, the optional nature of the AAA tool leaves it entirely to local governments to determine whether, when, and

and Inglis, as additional local governments making efforts to designate AAAs. SFRPC Guidebook, supra note 34, at 100-01; see also E-mail from Janet E. Bowman, Dir. of Legislative Policy \& Strategies, Fla. Chapter, The Nature Conservancy, to author (Apr. 5, 2016) (on file with author) (noting that the Yankeetown Natural Resource Adaptation Action Area was approved by referendum in early 2016). The City of Fort Lauderdale has adopted the concept of AAAs in its comprehensive plan and in its Strategic Plan. See CrTy OF FORT Lauderdale, Press Play Fort lauderdale: Our City, Our Strategic Pian 2018, at 29 (2013). The SFRPC reports that "the [AAA] language appears forty times in reference to infrastructure projects programmed in the City's Community Investment Plan." SFRPC Guidebook, supra note 34, at 73. The SFRPC Guidebook references Miami-Dade County's incorporation of Adaptation Action Areas into its 2013 update to its comprehensive plan. The plan's language provides:

By 2017, Miami-Dade County shall determine the feasibility of designating areas in the unincorporated area of the County as Adaptation Action Areas... in order to determine those areas vulnerable to coastal storm surge and sea level rise impacts for the purpose of developing policies for adaptation and enhance the funding potential of infrastructure adaptation projects.

SFRPC Guidebook, supra note 34, at 68 .

65. E-mail from Sean Allen Reiss to author, supra note 64.

66. E-mail from Sean Allen Reiss, Planning Analyst, Div. of Cmty. Dev., Fla. Dep't of Econ. Opportunity, to author (Nov. 12, 2015) (on file with author). The City of Fort Lauderdale has designated sixteen AAAs as well. E-mail from Nancy J. Gassman to author, supra note 16 (noting that "the City of Fort Lauderdale designated 16 AAAs in September 2015 as part of the adoption of its budget and Community Investment Plan").

67. E-mail from Sean Allen Reiss to author, supra note 64. 
where to use it. The limited nature of the local government obligation to review their comprehensive plans also may operate to reduce local government consideration of this option. ${ }^{68}$ Because AAAs are optional components of such plans, local governments whose plans come up for review have no obligation to consider AAAs as part of their review process.

Second, it remains to be seen whether the AAA designation will help attract funding for resilience-related work. The Southeast Florida Regional Climate Change Compact's Regional Climate Action Plan ("RCAP"), discussed in more detail below, ${ }^{69}$ indicates that AAAs are "expected to aid in focusing technical assistance and funding opportunities to areas most vulnerable to the impacts of sea level rise and coastal flooding."70 One sign that funding is a possibility is the State Senate's spring 2016 consideration of Senate Bill ("SB") 584, which would have authorized the Division of Emergency Management to administer a matching grant program to provide up to $\$ 50$ million in technical and financial assistance to local governments to implement flood risk reduction strategies. ${ }^{71}$ Local governments' use of the AAA mechanism may well depend on their perceptions concerning how much benefit they will gain by designating one or more areas as AAAs, by attracting outside funding or otherwise.

Finally, it also remains unclear to what degree the AAA concept will stimulate efforts to improve coordination across various planning and other fronts, both within the local government and between the local government and other stakeholders. ${ }^{72}$ As Table 1 above reflects, numerous opportunities exist for such coordination, ${ }^{78}$ but the jury is still out.

68. FLA. STAT. § 163.3191 (1) (2016).

69. See RCAP, supra note 32 ; infra Part IV.

70. RCAP, supra note 32 , at 14 .

71. S. 584, 2016 Leg. (Fla. 2016). This bill was not enacted during the 2016 legislative session.

72. See SFRPC Guidebook, supra note 34, at 49 (providing a table of existing planning tools that have the potential to influence, and be influenced by, AAA-related efforts). see also Erin Ryan, Negoliating Federalism, 52 B.C. L. REv. 1 (2011) (discussing the role of institutional structure in establishing the framework for negotiations and other interactions).

73. See RUPPERT \& STEWART, supra note 3. 


\section{SB 1094 (2015): PERIL OF FLOOD ${ }^{74}$}

In 2015, the Florida legislature enacted SB 1094, a law that imposes a new mandate on local governments to consider SLR and other factors that increase flood risk as part of the "redevelopment component" of the coastal management element of their

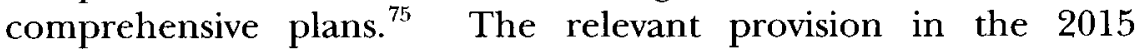
legislation, section 163.3178 of the Florida Statutes, provides as follows:

(2) Each coastal management element ... shall . . contain:

(f) A redevelopment component that outlines the principles that must be used to eliminate inappropriate and unsafe development in the coastal areas when opportunities arise. The component must:

1. Include development and redevelopment principles, strategies, and engineering solutions that reduce the flood risk in coastal areas which results from high-tide events, storm surge, flash floods, stormwater runoff, and the related impacts of sea-level rise.

2. Encourage the use of best practices development and redevelopment principles, strategies, and engineering solutions that will result in the removal of coastal real property from flood zone designations established by the Federal Emergency Management Agency.

3. Identify site development techniques and best practices that may reduce losses due to flooding and claims made under flood insurance policies issued in this state.

4. Be consistent with, or more stringent than, the flood-resistant construction requirements in the Florida Building Code and applicable flood plain management regulations set forth in 44 C.F.R. part 60.

5. Require that any construction activities seaward of the coastal construction control lines established pursuant to section 161.053 be consistent with chapter 161 .

6. Encourage local governments to participate in the National Flood Insurance Program Community Rating System

74. The opening sentence of Florida SB 1094 reads: "An act relating to the peril of flood." S. 1094, 2015 Leg. (Fla. 2015).

75. See 2015 Fla. Laws 64 . The 2015 statute has other features as well, but this Article focuses on the comprehensive planning issues. For discussion of these other features, see, for example, Deady \& Ruppert, supra note 4, at 9-10. 
administered by the Federal Emergency Management Agency to achieve flood insurance premium discounts for their residents. ${ }^{76}$

In a forthcoming publication, Thomas Ruppert and Alexander Stewart suggest that the 2015 law signals that concerns in the State about SLR are becoming more widely embedded. They suggest that " $[\mathrm{t}]$ he addition of another reference to sea-level rise, especially one that is mandatory in nature, highlights the realization that sealevel rise represents an important challenge to consider in the long-term resilience of Florida communities."77

I discuss below several features of the new law that are likely to shape implementation of SB 1094. These features raise questions concerning how effective this new provision will be in galvanizing local governments, as well as the State and interested citizens, to address the challenges posed by increased flood risks from SLR and other factors.

\section{A. Timing}

As noted above, local governments are required to reconsider their comprehensive plans every seven years to determine whether amendments are needed to reflect changes in state law. ${ }^{78}$ It does not appear that local governments will need to make special efforts to reconsider their plans to address the 2015 statutory change. Instead, it appears that they may do so at the time when they typically would reconsider their plans. ${ }^{79}$ Thus, for many of the governments subject to the 2015 amendments, there is likely to be a fair amount of lead time in working through their options for proceeding. ${ }^{80}$ Highlighting their view that timing is likely to be a

76. FLA. STAT. \$ 163.3178 (2016) (emphasis added). Florida's Coastal Construction Control Line ("CCCL") Program requires any buildings seaward of a CCCL to meet certain design standards and prevent loss of sediment from the site, among other requirements. See FLA. ADMIN. CODE ch. 62B-33 (2016).

77. See RUPPERT \& STEWART, sufra note 3, at 3.

78. FLA. STAT. $§ 163.3191(1)$. Local governments may decide that amendments are needed sooner than required by the seven-year provision and they may voluntarily update their plans to address the 2015 legislation before their next state coordinated review. Id. $\S$ $163.3191(2)$.

79. Id. \$163.3161 (12); Deady \& Ruppert, supra note 4, at 10.

80. Georgetown Climate Center, Florida SB 1094: "An A Relating lo the Peril of Flood", http://www.georgetownclimate.org/resources/florida-sb-1094-an-act-relating-to-the-peril-offlood [https://perma.cc/B37B-4GQ8] (last visited Jan. 3, 2016). 
key feature in the implementation of the 2015 law, Erin Deady and Thomas Ruppert observe that the question of whether local governments need to consider future SLR in addressing and minimizing flood risk "is not if, it's when." 81

\section{B. "Inevitability" of Local Government Review}

It remains to be seen whether the inevitability of local government consideration of SLR and flood risk is as open-andshut as Deady and Ruppert suggest. Both the law and early experience offer some grounds for skepticism. A brief detour into the weeds of Florida's comprehensive planning process explains why. State law creates two mechanisms for review of the vast majority of local government comprehensive plan efforts: a "state coordinated review" process and an "expedited state review" process. ${ }^{82}$ The state coordinated review process is used when a local government has proposed an update to its comprehensive plan based on an evaluation and appraisal. ${ }^{83}$ The process is detailed in section 163.3191 of the Florida Statutes, which requires each local government to evaluate its comprehensive plan at least once every seven years to "determine if plan amendments are necessary to reflect changes in state requirements . . . since the last update of the comprehensive plan." ${ }^{" 4}$ The local government is to "notify [DEO] as to [the local government's] determination" concerning whether plan amendments are necessary. ${ }^{85}$ The statute continues: "If the local government determines amendments to its comprehensive plan are necessary to reflect changes in state requirements, the local government shall prepare... such... amendments for review" within one year. ${ }^{86}$ Thus, the statecoordinated review process vests considerable discretion in a local government to determine whether it needs to amend its comprehensive plan in light of intervening changes to State law.

81. Deady \& Ruppert, supra note 4 , at 10.

82. FLA. STAT. $\$ 163.3184$ (2)(c), (3). Different mechanisms exist for particular types of comprehensive plan amendments. See e.g., id. $\$ 163.3184(2)(\mathrm{a})-(\mathrm{b}),(3)$ (a) (providing that the expedited review process shall apply to all amendments except those that qualify as "small-scale development amendments," which may follow the small-scale review process).

83. Id. $\$ \S 163.3184(2)(\mathrm{c}), 163.3191$.

84. Id. $\$ 163.3191$ (1) (emphasis added).

85. Id.

86. Id. $\S 163.3191$ (2) (emphasis added). 
At this point, it is difficult to say how local governments will conduct the review required under the 2015 law. ${ }^{87}$ The evidence suggests there will be, at the very least, uneven results. Local governments subject to the 2015 legislation have submitted nine notification evaluation letters to DEO as of November 9, 2015. These letters suggest that the possibility that a local government may decide not to amend its comprehensive plan in order to address the requirements of the 2015 law is not simply theoretical. Several of the local governments that have made submittals through the state-coordinated review process since the adoption of the 2015 legislation have determined they do not need to amend their comprehensive plans in order to conform to the new State requirements. $^{88}$ The table below reflects the assessments of these nine local governments of the need to amend their comprehensive plans, as well as DEO's responses.

87. See E-mail from Ray Eubanks, Plan Processing Adm'r, Fla. Dep't of Econ. Opportunity, to author (Nov. 18, 2015) (on file with author). Section 163.3191(4) provides that a local government may not amend its comprehensive plan if it fails to submit its letter notifying DEO whether the local government believes amendments to address recent changes in state law are needed, or if it fails to update its plan if it determines that such amendments are needed. This provision arguably creates an incentive for a local government at least to notify the State of its position.

88. E-mail from Ray Eubanks to author, supra note 87. These letters are commonly referred to as "evaluation and appraisal" notifications. See FLA. STAT. § 163.3191(2). 
Table $2^{89}$

\begin{tabular}{|c|c|c|c|c|}
\hline & $\mathrm{Y}^{*}$ & $I^{*}$ & $\mathrm{~N}^{*}$ & DEO Response \\
\hline Indian Shores & $\mathrm{X}$ & & & State-coordinated review process \\
\hline Boynton Beach & $\mathrm{X}$ & & & State-coordinated review process \\
\hline Oldsmar & & & $\mathrm{X}$ & $\begin{array}{l}\text { Acknowledges local position that no } \\
\text { changes are needed and identifies the } \\
2015 \text { changes to } 163.3178 \text { and SLR }\end{array}$ \\
\hline Jupiter Inlet Colony & & & $\mathrm{X}$ & $\begin{array}{l}\text { Acknowledges local position that no } \\
\text { changes are needed and identifies the } \\
2015 \text { changes to } 163.3178 \text { and SLR }\end{array}$ \\
\hline Lauderdale-by-the-Sea & & & $\mathrm{X}$ & $\begin{array}{l}\text { Acknowledges local position that no } \\
\text { changes are needed and identifies the } \\
2015 \text { changes to } 163.3178 \text { and SLR }\end{array}$ \\
\hline Lake Park & $\mathrm{X}$ & $\mathrm{X}$ & & State-coordinated review process \\
\hline Miami & $\mathrm{X}$ & & & State-coordinated review process \\
\hline Ponce Inlet & $\mathrm{X}$ & $\mathrm{X}$ & & State-coordinated review process \\
\hline Volusia County & & & $\mathrm{X}$ & $\begin{array}{l}\text { Acknowledges local position that no } \\
\text { changes are needed and identifies the } \\
2015 \text { changes to } 163.3178 \text { and SLR }\end{array}$ \\
\hline
\end{tabular}

$* \mathrm{Y}=$ comprehensive plan amendments needed

*I $=$ if comprehensive plan amendments needed, identified F.S. 163.3178

$* \mathrm{~N}=$ comprehensive plan amendments not needed

Of the nine local governments that must prepare coastal management elements and that have been required to submit notifications since the adoption of the 2015 Peril of Flood legislation, four (44\%) concluded that they do not need to amend their comprehensive plans-Jupiter Inlet, Volusia County, Oldsmar and Lauderdale-by-the-Sea. DEO acknowledged the letter submission from each of the local governments and has notified each of the 2015 changes to section $163.3178 .^{90}$ Of the five local governments that notified the State that they planned to amend

89. The information in Table 2 derives from local "evaluation and appraisal" notifications sent by DEO to the author. E-mail from Ray Eubanks to author, supra note 87. Mr. Eubanks indicated that two local governments have submitted amendments to address the 2015 legislation, Cutler Bay and Pinecrest.

90. DEO has now included the advisory language in letters to Oldsmar and Lauderdaleby-the-Sea letters even though it had not done so initially. DEO advised that it included this language as a courtesy to the local governments, not because doing so was statutorily required. Id. 
their comprehensive plans, three did not specify the reasons for their determination that amendments were needed. Two specifically referenced the need to address the 2015 Peril of Flood legislation: Lake Park and Ponce Inlet. ${ }^{91}$

The current sample size of nine is obviously small-fewer than $5 \%$ of the local governments that ultimately will need to submit such reports have had to do so already. The relatively recent enactment of the Peril of Flood legislation may have contributed to the nature of the early local government response as well. Nonetheless, the fact that almost $50 \%$ of those submitting have neither acknowledged the existence of the 2015 legislation, nor its effect on their obligations, raises questions about whether implementation of the law is likely to be seamless. The fact that only two of the nine local governments clearly acknowledged that the 2015 peril of flood legislation required amendments to their respective comprehensive plans does as well. At a minimum, implementation warrants close follow-up to learn why local governments to date do not appear to be responding to the 2015 law through the legal mechanism created for that purpose. ${ }^{92}$ Thus, in addition to the timing issue referenced above, the extent to which local governments are likely to make a meaningful effort to comply with the 2015 law remains in question. ${ }^{93}$

\section{Relevant and Appropriate Data}

The requirement in Florida law that a local government comprehensive plan be based on "relevant and appropriate data"94 has the potential to raise significant substantive issues in the implementation of the 2015 law. $^{95}$ Section $163.3177(1)$ imposes the following requirements in terms of supporting data:

91. $I d$.

92. See FLA. STAT. $\$ 163.3184(4)$ (c)-(d) (2016) (setting forth DEO's role in reviewing local amendments).

93. Full treatment of this issue is beyond the scope of this Article. For example, the statute's imposition of conditions on a local government's legal authority to amend its comprehensive plan may influence local governments to consider the 2015 requirements. See id. $\$ 163.3191(4)$.

94. Id. $\S 163.3177$ (1)(f) (providing that a comprehensive plan "shall be based upon relevant and appropriate data and an analysis by the local government that may include... surveys, studies,... and other data available at the time of adoption of the comprehensive plan or plan amendment").

95. Deady \& Ruppert, supra note 4, at 10 (describing the task as follows: "There are numerous [data] resources for considering future flood risk in Comprehensive Plans and the 
(f) All mandatory and optional elements of the comprehensive plan and plan amendments shall be based upon relevant and appropriate data .... To be based on data means to react to it in an appropriate way and to the extent necessary indicated by the data available on that particular subject at the time of adoption of the plan or plan amendment at issue.

2. Data must be taken from professionally accepted sources. ${ }^{96}$

One substantive issue likely to arise involves the data or information a local government must consider in proposing an amendment. On one end of the data spectrum, it seems clear that the statute does not obligate local governments to develop new data on their own. ${ }^{97}$ Beyond that baseline point, local governments face an unsettled legal landscape as they seek to support their planning with the required relevant and appropriate data. For example, as discussed below, the Sea Level Rise Work Group ("SLR Work Group") of the Southeast Florida Regional Climate Change Compact (the "Southeast Compact" or the "Compact") recently issued an updated version of its unified sea-level projection with specific "guidance" concerning local governments' use of this projection in planning. ${ }^{98}$ This guidance "contains directions and specific examples of how the projection can be used by local governments, planners, designers and engineers and developers." ${ }^{99}$ It is unsettled at this point to what extent a local government will be expected to stay abreast of such guidance and similar developments and to consider them. Local governments, and others, including ultimately the courts in some cases, will

beauty will be in the eye of the beholder. But local governments should consider the source of data to meet these requirements and whether or not it is appropriate under the circumstances."); E-mail from Ray Eubanks to author, supra note 87 (noting that the statute "does not clearly define 'relevant and appropriate data").

96. FLA. STAT. § $163.3177(1)$

97. See id. (mandating that data be taken from "professionally acceptable sources," and noting that a local government "may use" original data to support elements of its comprehensive plan and that "[o]riginal data collection by local governments is not required" (emphasis added)); see also Pacetta, LLC v. Town of Ponce Inlet, 2012 WL 993258, at $* 10$ (Fla. Div. Admin. Hrgs. 2012) (noting that "local governments are not required to collect original data").

98. Se. Fla. Reg'l Climate Change Compact Sea level Rise Work GrP., Unified Sea LEvel Rise Projection (2015) [hereinafter SEA LEVEL RISE WORK GRP.].

99. Id. at 2 . 
undoubtedly need to sort through challenging questions about the "relevance" and "appropriateness" of different types of data and other forms of information as such information becomes increasingly available, and as its value for local decision-makers increases. $^{100}$

\section{Relevant Time Frame for Assessing Risk}

Another key question that relates to the 2015 legislation involves the time frame local governments will use in assessing risk. Section $163.3177(5)(a)$ of the Florida Statutes requires that a local government include at least two planning periods in its comprehensive plan, the five-year period following adoption of the plan, and at least a ten-year period. ${ }^{101}$ Many of the SLR models project that SLR will accelerate during the latter part of the twentyfirst century and that some significant impacts will not occur for decades. ${ }^{102}$ Deady and Ruppert have asked whether it would be worthwhile to develop best practices for looking out forty, fifty, or more years, as some communities are already doing. ${ }^{103}$ In its

100. In addition to a local government determining that it meets the relevant and appropriate standard, and DEO having the capacity to review this determination, an administrative law judge may need to make a determination about compliance in a contested proceeding, with a final order entered by DEO or the governor and cabinet. FLA. STAT. \$ 163.3184(4)-(5). A handful of Florida cases have considered the "relevant and appropriate" requirement in different contexts. See, e.g., Indian Trail Improvement Dist. v. Dep't of Cmty. Affairs, 946 So. 2d 640, 641 (Fla. Dist. Ct. App. 2007) (noting that the same amount and types of data are not required for all amendments); Payne v. City of Miami, 52 So. 3d 707, 741 (Fla. Dist. Ct. App. 2010) (highlighting the importance, in connection with Florida's concurrency requirements and the use of "relevant and appropriate data," of using data rather than relying on assumptions during the planning process). The dynamic character of the data and analyses will pose special challenges. See, e.g., SEA LEVEL RISE WORK GRP., supra note 98 (discussing increasing knowledge of the combined effects of sea-level rise and storm surge); America's Preparedness Report Card, STATES AT RISK, http://reportcard.statesatrisk.org [https://perma.cc/YDB7-L9RJ] (last visited Jan. 3, 2016) (providing the "[f]irst-ever national analysis of state-level preparedness for climate-driven threats"); Surging Seas, Climate CENT., http://sealevel.climatecentral.org [https://perma.cc/YA66-XX94] (last visited Nov. 8, 2015).

101. FLA. STAT. $\$ 163.3177(5)$ (a).

102. GORNITZ, supra note 43, at 254 (noting that "most ... sea level projections show a gradual, nearly linear trend for several decades before a rapid acceleration later in the century"). Gornitz observes that "[a] sharp disconnect exists between short election cycles, business planning for this year's or next year's profits, or even a human life span versus the much longer timescales over which climate evolves." Id. at 254.

103. Deady \& Ruppert, supra note 4, at 10. Sarasota, which embarked several years ago on its "Sarasota 2050" planning effort, is an example of a community that is looking out about forty years. See Sarasola 2050 Policy, SARASOTA COUNTY, https://www.scgov.net/ 
October 2015 Unified Sea Level Rise Projection, the Compact's SLR Work Group suggests that longer horizons be used in some circumstances. ${ }^{104}$ Local government decisions about which time frames to use are likely to be important data points in the implementation of the new law and are likely to affect the content of future decisions. The 2011 legislation increases the flexibility of local governments to use different planning periods so that, for example, a local government could use a fifty-year coastal management element to address SLR, while using a ten-year planning period for the rest of the plan. ${ }^{105}$

\section{E. The Content of Local Plans}

Another implementation issue that has yet to play out involves the choices local governments will make among available strategies to promote resilience to flood risk from SLR and related factors. As noted above, commentators have divided possible strategies into several categories, including protection, accommodation, and retreat ("PAR"). ${ }^{106}$ On one hand, by requiring that each local government develop principles that it must use to "eliminate" inappropriate and unsafe development when opportunities arise, the State seems to be creating an expectation that each government will "eliminate" certain development in at least some cases. $^{107}$ Similarly, by requiring that each coastal management element encourage approaches that will "result in the removal of

compplan/pages/sarasota2050.aspx [https://perma.cc/Q76K-QGB9] (last visited Nov. 25, 2016).

104. SeA LeVEL RISE WORK GRP., supra note 98, at 1. The SLR Work Group extended the projection in its 2015 report to 2100 "in recognition of the need for longer range guidance for major infrastructure and other long term investments now being planned."

105. Prior to the 2011 legislation, the State land planning agency had imposed a uniform planning period throughout each plan. The 2011 legislation provides that "additional planning periods for specific components, elements, land use amendments, or projects shall be permissible." FLA. STAT. $\$ 163.3177(5)$ (a). This provision diminishes the effect of the internal consistency requirement for comprehensive plans but seems to make sense when different planning horizons are appropriate for different parts of a plan. One exception is that the statute retains the requirement that consistent data generally be used "where data is relevant to several elements." Id. § $163.3177(2)$.

106. See supra note 43 and accompanying text.

107. The concept of "inappropriate and unsafe development" is not defined in the statute, which may well be a source of additional uncertainty as the statute is implemented. This phrase predates the 2015 amendments. See James Wilkins, Is Sea Level Rise "Foreseeable"? Does It Matter?, 26 J. LAND USE \& ENVIL. L. 437, 459 (2011) (discussing scenarios where this concept may apply and its implications compared to other states). 
coastal real property," 108 the State is at least implicitly indicating that less stringent and less intrusive measures may not always be enough to reduce flood risk sufficiently. Thus, the legislation appears to be intended to provide a normative signal to local governments that the State expects them to act to reduce flood risks. ${ }^{109}$ The law's affirmation that local governments must adhere to already extant building code and flood plain management regulations and coastal construction control lines requirements arguably reinforces the legislature's desire to impress on local governments the seriousness of the challenge. ${ }^{10}$

On the other hand, much of the new law is considerably less determinate in its approach. The provision cited above-“[e]ach coastal management element... shall... contain... [a] redevelopment component that outlines the principles that must be used to eliminate inappropriate and unsafe development in the coastal areas when opportunities arise"11-obviously includes wiggle room that leaves considerable discretion about its implementation to local governments. For example, it is up to local governments to develop the principles they will use to eliminate certain development. Similarly, as noted above, the concept of "inappropriate and unsafe" development is not defined in the statute. And, presumably, it is up to a local government in the first instance to decide "when opportunities arise" that trigger any principles it has established to guide decisions to eliminate certain development.

There is additional ambiguity in the statutory direction since the State has not directed or mandated that local governments pursue any particular level of risk reduction or achieve any specific degree of resilience. ${ }^{112}$ State law similarly does not require that local governments employ particular principles, strategies, or engineering solutions. ${ }^{113}$ Instead, the 2015 law "encourages" local

108. FLA. STAT. $\$ 163.3178(2)(f)(2)$.

109. Other examples of the intent to provide such normative direction include the express requirement in the statute that each local government not only consider retreat as an option, but also develop principles to implement that strategy. In addition, the statute expressly requires that each local government include principles, strategies, and engineering solutions that reduce flood risk. $I d . \S 163.3178$.

110. See id. $\$ 163.3178(2)$ (f).

111. $I d$.

112. See infra note 214 (discussing the challenges in establishing metrics).

113. See FLA. STAT. $\$ 163.3178(2)$ (f) (1). 
governments to pursue certain approaches; ${ }^{114}$ it directs local governments to "identify" desired techniques and practices but does not require their implementation; ${ }^{115}$ and it "encourages" local governments to participate in the National Flood Insurance Program Community Rating System." 116

At its core, the 2015 State legislation puts a large menu of possible strategies on the table for local governments to consider in order to reduce flood risk through comprehensive planning. The statute seems to evince the State's strong desire that local governments plan to address such risks, but it remains to be seen how local governments will exercise their authority in choosing among different strategies and to what degree, and in what ways, the State, affected persons, and ultimately the courts engage in such efforts.

Another substantive question involves the tools local governments will choose to use to implement the strategies they select. The SFRPC has identified seventeen such tools in the 2015 SFRPC Guidebook, as discussed above. ${ }^{117}$ Because the statute appears to preserve enormous latitude for local governments to choose particular tools for particular situations, local government preferences are especially likely to prevail in this arena.

A recent article suggests that many of the local governments in Florida that are considering adaptation are focusing on "noregrets" and "low-regrets" initiatives at this stage because of the uncertain benefits of adaptation efforts and their clear financial, opportunity, and political costs:

In the face of uncertain long-term benefits of climate change adaptation and more easily calculated short-term capital, opportunity, and political costs, public sector decision makers, and even adaptation advocates, are promoting risk reduction through noregrets and low-regrets initiatives. No-regrets measures reduce climate change vulnerability but provide sufficient other benefits to be justifiable, even in the absence of anticipated climate change impacts. Low-regrets measures require relatively small short-term 
investments for relatively large anticipated climate adaptation benefits. $^{118}$

The article suggests that the decision to begin with "low-regrets" strategies " $[\mathrm{m}]$ irror $[\mathrm{s}]$ the well-documented trends in natural hazard mitigation" over the past forty years. ${ }^{119}$

A final feature of the 2015 legislation that is worth mentioning is the legislature's recognition that the goal of future community wellbeing (here, protection from flood risk due to sea-level rise and other factors) has become a moving target. Local governments must reduce future flood risk based on an understanding of the nature and extent of that risk stemming from historic events (e.g., past flooding), with the goal of preparing for a future for which we have no analog, at least not in recent times. ${ }^{120}$ The no-analog character of the task adds enormously to the challenge of governing effectively. Navigating this uncharted terrain is likely to test the capacity of government officials and civil society alike, especially given a real-world environment characterized by significant gaps in such capacity (technical, financial, mechanisms for coordination, etc.).

\section{F. State Review}

The 2015 statute, when read with existing law, raises a series of additional substantive issues relating to the scope of outside (especially government and "affected person") review. ${ }^{121}$ DEO's review authority in the state coordinated review process includes the power to "make objections, recommendations, and comments ... regarding whether the plan or plan amendment is in compliance and whether the plan or plan amendment will adversely

118. Butler et al., sufra note 3 , at 321 (citations omitted).

119. Id. at 327 (citations omitted). The authors suggest that local governments are mindful that, because of the complexity and uncertainty associated with flood concerns due to sea-level rise and other factors, there is a significant potential for local governments to "over- and underadapt[]." Id. at 319 (citation omitted).

120. J.B. Ruhl, Climate Change and the Endangered Species Act: Building Bridges to the No Analog Fulure, 88 B.U. L. REV. 1, 11 (2008) (noting that “[m]any ecologists believe we face a no-analog future--one for which we have no experience on which to base projections of ecosystem change"). For a summary of both the accelerating nature of SLR in Florida, and the "substantial uncertainty" that exists about the rate of future SLR, see Butler et al., supra note 3 , at $319-20$.

121. FLA. STAT. $\$ 163.3184(1)(a)$. 
impact important state resources and facilities." ${ }^{22}$ Under the expedited review process for comprehensive plans created by the legislature in $2011,{ }^{123}$ the reviewing State agencies are limited to commenting on "important state resources and facilities that will be adversely impacted by the amendment if adopted." 124

It remains to be seen how state agencies, including DEO, will exercise their authority to evaluate whether a local government plan conforms to state law, including the 2015 legislation. ${ }^{125}$ For example, Robert Rhodes, former Chair of the Environmental Law and Land Use Section of the Florida Bar, has suggested that the definitions of some key terms are indeterminate and likely to lead to considerable confusion:

[T]he 2011 Act doesn't define the new operative terms [i.e., "important state resources and facilities" and "adversely impacted"]. Instead, potentially ten different agencies will determine if a plan amendment will adversely impact an important state resource or facility ....

Lacking basic definitions for these seminal terms, the new process will likely produce fragmented, situation based, incremental policy that undercuts the surviving state oversight role. . .

This lack of clear, consistent state policy favors no one....

Local governments and applicants will have to deal with several state and regional agencies which may comment on amendments

122. Id. $\S 163.3184$ (4)(d)(1) (emphasis added). "In compliance" means consistent with the requirements of sections 163.3177, 163.3178, 163.3180, 163.3191, 163.3245, and 163.3248 , with the appropriate strategic regional policy plan, and with the principles for guiding development in designated areas of critical state concern and with part III of chapter 369, where applicable. Id. $\$ 163.3184(1)$ (b).

123. The expedited review process is intended to cover most comprehensive plan amendments other than the amendments submitted pursuant to the state coordinated review process. See id. $\$ 163.3184(2)-(3)$ (noting that the expedited review process shall apply to all amendments except those that qualify as "small-scale development amendments," which may follow the small-scale review process; that are in an area of critical state concern; that propose a rural land stewardship area; that propose a sector plan; that update a comprehensive plan based on an evaluation and appraisal; that propose a development that qualifies as a development of regional impact; or that are new plans for newly incorporated municipalities); see also Rhodes, supra note 27, at 17 (reporting that "[f] or year 2012, 87\% of 341 proposed amendments received expedited state review").

124. FLA. STAT. \$ $163.3184(3)$ (b) (2); see also Rhodes, supra note 27, at 17 (noting that, under expedited review, DEO and other government reviewers "must restrict their review of plan amendments to whether the amendment will adversely impact important state resources or facilities," and that DEO may only challenge a plan amendment "if it determines there will be an adverse impact to important state resources or facilities").

125. FLA. STAT. $\$ 163.3184$ (4)(d)(1). 
based on particular situations and apply current and potentially changing agency and administration preferences and biases. The state planning agency will be mightily challenged to coordinate, integrate, and develop a rational state policy from all this. ${ }^{126}$

Rhodes's proposal is that the legislature define the key "operative terms": "important state resources and facilities, and adverse impact." ${ }^{127}$ Absent clarification, there is significant potential for confusion.

In sum, while the 2015 legislation by its terms mandates that many of Florida's local governments prepare a redevelopment component as part of their comprehensive plan in order to eliminate inappropriate and unsafe development in the coastal areas when opportunities arise, among other things, there is considerable uncertainty in the legal landscape that will shape such efforts. It is far too early to know how this mandate will be implemented, and how much flood-related and other risks will be reduced.

\section{The Southeast Florida Regional Climate Change COMPACT}

The Compact that four Southeast Florida counties-Broward, Miami-Dade, Monroe, and Palm Beach (the "Compact Counties")—adopted in 2010 has been characterized as one of the most innovative efforts to promote coordinated adaptation work in the United States. ${ }^{128}$ In this overview, the Article focuses on two aspects of the Compact: (1) its origins and structure, and (2) its outcomes to date. ${ }^{129}$

126. Rhodes, supra note 27, at 17; see also E-mail from Ray Eubanks to author, supra note 87 (agreeing that the legislature has not defined these concepts).

127. Rhodes, supra note 27 , at 18.

128. See GCC CASE STUdiES, supra note 3, at 1. The Compact has won awards from the International Council for Local Environmental Initiatives and the National Association of Counties, and it has been recognized by the White House. RCAP, supra note 32, at 2 (describing several instances of such recognition).

129. See generally Ray \& Grannis, supra note 2, at 22 (asserting that the Compact "warrant[s] more attention from scholars"). This Section provides an overview of the Compact rather than a comprehensive review of its activities. The Compact's website, http://www.southeastfloridaclimatecompact.org, includes a rich trove of materials. Georgetown's Climate Center is also developing a detailed assessment of the Compact's experience. The author appreciates the Center's willingness to share its very helpful draft assessment. 


\section{A. Origins}

To at least some degree, the four counties located in Southeast Florida formed a compact because of frustration they experienced through independent efforts to attract federal attention to their climate change concerns. As the Compact's Regional Climate Action Plan ("RCAP") puts it:

In the spring of 2009, several Southeast Florida counties and cities were making the rounds in the halls of Congress to advocate for climate policy. A great deal of work had been invested individually by each jurisdiction; however, each had slightly different baseline emissions figures at different points of time and different sea level rise planning scenarios. The need for regional coordination became quite evident.... That realization [that there is an obvious and unique strength in the region's size and its numbers] paved the way for a unique arrangement-the Compact-a voluntary and cooperative partnership among governing bodies to tackle one of, if not the most important issue facing our generation. ${ }^{130}$

A 2015 Georgetown Climate Center review offers a similar perspective concerning the origins of this coordinated regional effort:

Prior to 2009, the Compact counties were addressing climate impacts individually but county leaders quickly recognized the need to coordinate their efforts when they were visiting Congressional leaders in Washington DC in the spring of 2009. Each county had invested significant resources developing carbon emissions baselines and sealevel rise scenarios, but when county leaders were discussing the challenges posed by climate change to their region with legislative staff each county was citing different numbers and projections. This left Congressional staff unconvinced by the conflicting projections, and exposed the need for the counties to work together and speak with one voice. ${ }^{131}$

Elected officials from each of the four counties agreed to jointly host a regional climate summit that they hoped would "serve as a

130 RCAP, supra note 32, at 1; see also id. at 7 ("At the first Regional Climate Leadership Summit, the local diversity in [SI.R] projections was highlighted as a concern, and a barrier, to achieving regionally consistent adaptation policies and demonstrating a coordinated local effort to higher decision-making levels.").

131. GCC CASE STUDIES, supra note 3 , at 3 (footnotes omitted). 
platform for broader discussion among county and municipal elected officials and the community as to the pressures and challenges that climate change poses for Southeast Florida with a call for unified action." ${ }^{32}$ A few months later, the four county commissions together held the 2009 Regional Climate Leadership Summit. This summit led to the ratification of the Compact by January 2010. ${ }^{133}$ Each county adopted the Compact by unanimous vote of its county commission. ${ }^{134}$ Reflecting the innovative character of this multi-county collaboration, Georgetown's Climate Center described the Compact as "the first example where U.S. counties voluntarily committed to work at the regional scale to adapt to climate change impacts. So rather than prepare for impacts solely within jurisdictional boundaries, the four Compact counties agreed to build resilience to future climate impacts together throughout the southeast Florida region." ${ }^{135}$

The Compact is administered by a Steering Committee, which includes two voting members from each member county, as well as a voting member from one municipality located within each county. ${ }^{136}$ A significant number of other organizations are actively involved in the work of the Compact. Regional organizations include the SFRPC and the South Florida Water Management District. At the federal level, the U.S. Army Corps of Engineers ("USACE"), the U.S. Environmental Protection Agency ("USEPA"), and the National Oceanic and Atmospheric Administration ("NOAA") are all participating. In addition, nongovernmental organizations ("NGOs"), including The Nature Conservancy, as well as academic institutions, are also actively involved in the work of the Compact. ${ }^{137}$

Another indispensable actor is the Institute for Sustainable Communities ("ISC"), a non-governmental organization that has provided essential logistical and other support for the Compact's work, made possible by a close to $\$ 1$ million grant from the Kresge

132. RCAP, supra note 32 , at 1 .

133. Id. at 1. The counties have held annual summits. GCC CASE STUdies, supra note 3, at 8 .

134. RCAP, supra note 32 , at 1 .

135. GCC CASE STUDIES, supra note 3 , at 1 .

136. RCAP, supra note 32 , at 1 . "There are more than 100 local city governments in the region, each at [a different stage] of climate mitigation and adaptation planning and implementation." Id. at 12.

137. GCC CASE STUdies, supra note 3 , at 1 . 
Foundation. ${ }^{138}$ The role of ISC in particular deserves close attention because it has been an integral part of the Compact and has played an important role in the Compact's work. ${ }^{139}$ As the Compact's 2014 Municipal Implementation Survey Report, prepared by ISC, reflects, the Compact "has partnered with the [ISC] ... to pioneer a regional climate governance model." 140

\section{B. Actions to Date}

The Compact effort has produced several documents thus far. Four are especially relevant to adaptation. ${ }^{141}$

\section{Unified Sea-Level Rise Projections (2011 and 2015)}

In 2011, the Compact's Technical Ad Hoc Work Group (a precursor to the SLR Work Group) produced a uniform projection for SLR for the region. ${ }^{142}$ The work group recommended that the Compact revisit projected sea-level rise in four years because of the dynamic nature of their work. ${ }^{143}$ That reappraisal was completed in October 2015 by the SLR Work Group. ${ }^{144}$

In its 2015 report, the SLR Work Group found that sea-level rise has accelerated in the Southeast Florida area (as well as nationally) in recent years, and that additional flooding has resulted:

138. Id. at 1,7 (noting that the ISC accepted a $\$ 975,000$ grant from the Kresge Foundation in 2012 to support the Compact and that "[b]ecause the Compact is not a formal legal entity, it must work through a fiscal agent [the ISC] to take in funding"); see also Grants Awarded: Institute for Sustainable Communilies, KRESGE FOUNDATION, http://kresge.org/ grants-social-investments/grants/institute-for-sustainable-communities-0 [https://perma.cc/ MZ9J-N66N] (last visited Nov. 8,2015 ) (discussing the $\$ 975,000$ grant awarded to the ISC to help implement the Southeast Florida Regional Climate Change Compact).

139. GCC CASE STUDIES, supra note 3, at 14 (reviewing the ISC's extensive contributions to the work of the Compact, which include administering the survey that led to the ISC's preparation of the 2014 Municipal Implemenlation Survey Report). As the 2014 Municipal Implementation Survey Report notes, the survey will "allow the Compact and ISC to create a database... highlighting municipal work in mitigating and adapting to climate change impacts and will allow for peer-to-peer knowledge and resource sharing." SURVEY REPORT, supra note 3 , at 4 . Whether this type of accountability and clearinghouse work would be undertaken without the ISC is not clear.

140. SURVEY REPOR'T, supra note 3 , at 3 .

141. The Compact's work relating to mitigation includes development of a regional greenhouse gas baseline. RCAP, supra note 32, at 2 .

142. Se. Fla. Reg'l Climate Change Compact Tech. Ad Hoc Work GrP., A Unified Sea LEVEL RISE PROJECTION FOR SOUTHEAST FLORIDA (2011).

143. Id. at iii.

144. SEA LeVEL Rise WORK GRP., supra note 98; E-mail from Nancy J. Gassman to author, supra note 16. 
Recent analyses of tide gauge records acquired along the US Atlantic coast indicate a rapid acceleration in the rate of sea level rise since $2000 \ldots$ The higher sea level resulted in increasing flooding frequency in several coastal communities, e.g., ... Miami Beach. ... These frequent flood events, often termed "nuisance flooding," occur mainly due to heavy rain during high tide conditions .... Recently, [a study] used tide gauge data to calculate accumulated flooding time in twelve locations along the Atlantic coast and showed a significant increase in flooding duration over the past twenty years. ${ }^{145}$

The SLR Work Group projected that sea level will continue to rise over the next several decades: "In the short term, sea level rise is projected to be 6 to 10 inches by 2030 and 14 to 26 inches by 2060 (above the 1992 mean sea level)... In the long term, sea level rise is projected to be 31 to 61 inches by $2100 . " 146$

The SLR Work Group identified a variety of adverse impacts from projected sea-level rise, including physical impacts and socioeconomic effects:

The consequences associated with sea level rise include direct physical impacts such as coastal inundation of inland areas, increased frequency of flooding in vulnerable coastal areas, increased flooding

145. SEA LEVEL RISE WORK GRP., supra note 98, at 9 (citations omitted). The report noted that " $[t]$ he National Aeronautics and Space Administration Jet Propulsion Laboratory has reported the average global sea level has risen almost 3 inches between 1992 and 2015 based on satellite measurements. Sea level rise in South Florida has been of similar magnitude over the same period but is anticipated to outpace the global average due to ongoing variations in the Florida Currents and Gulf Stream." Id. at 1 (citations omitted). The SLR Work Group also noted that "continued analysis of changes in trends over time is necessary to determine [the] long-term significance of this recently observed uptrend, [but] studies have already begun to correlate the regional sea level rise to the slowing down of the Gulfstream." Id. at 9 . For example, the report notes that "[a] statistically significant acceleration of sea level rise has been documented in the latter half of the 20th century continuing through recent years." Id. app. B at 26 (citations omitted). Consistent with current guidance from USACE and NOAA, the 2015 projection uses a 1992 starting date (rather than the 2010 starting date used in the 2011 projection). Id. app. E at 35 .

146. Id. at 13. The SLR Work Group qualified its projection for the medium and long term by noting "a significant range of variation as a result of uncertainty in future greenhouse gas emissions and their geophysical effects, the incomplete quantitative understanding of all geophysical processes affecting the rate of sea level rise in climate models and current limitations of climate models to predict the future." Id. at 4 . It also noted that "the development of complex climate models is evolutionary and many processes and responses are yet to be incorporated. The numerous ice melt accelerating feedbacks not in the models are especially of concern as they are speeding up ice melt and sea level rise well beyond model projections." Id. at 8 . 
in interior areas due to impairment of the region's stormwater infrastructure i.e. impacts to gravity drainage systems and features in the regional water management canal system, saltwater intrusion into the aquifer and local water supply wells, and contamination of the land and ocean with pollutants and debris and hazardous materials released by flooding. Consequences also include cascading socioeconomic impacts such as displacement, decrease in property values and tax base, increases in insurance costs, loss of services and impaired access to infrastructure. The likelihood and extent to which these impacts will occur is dependent upon the factors influencing the rate of sea level rise such as the amount of greenhouse gases emitted globally, rate of melting of land-based ice sheets, the decisions and investments made by communities to increase their climate resilience and ... many interconnected processes. ${ }^{147}$

In addition to its findings regarding past sea-level rise and its projections for future changes in sea levels and their impacts, the SLR Work Group "provides guidance for the Compact Counties

\section{Id. at 2. The SLR Work Group also determined as follows:}

Storm surge and sea level rise are independent coastal processes that when occurring simultaneously lead to compounded impacts. Sea level rise will increase the inland areal extent inundated by surges, the depth of flooding and power of the surge and the extent and intensity of damage associated with storm surge and waves. As a result, severe storms of the future will cause more damage than storms of equal intensity occurring at today's sea level. Tebaldi et al. (2012) estimate a 100-year magnitude surge flooding (by today's standards) will begin to occur every 20 years at the projected mean sea level in 2050. Regional hazard mapping does not yet include the combined effects of sea level rise and surge but the impacts are anticipated to be significant.

$I d$. at 10 . The SLR Work Group elaborated on the increased risks associated with sea-level rise as follows:

As sea level rise increasingly inundates coastal areas, there is the potential for degradation of natural resources and loss of their services to the surrounding environment. Ecosystems will transition either by retreat and migration, adaptation, or elimination of functions and certain species. Shallow water habitats may transition to open water, forcing ecological changes in coastal wetlands and estuaries affecting nesting, spawning and feeding locations and behavior. Intrusion of saltwater inland, into inland water bodies and within the aquifer is negatively impacting freshwater resources, and these impacts will worsen or accelerate with further sea level rise. Inundation of shorelines will increase the extent and severity of beach erosion and previously stable coastal areas. In combination, these impacts will cascade throughout the region's ecosystems even if they are not immediately adjacent to open water areas.

Natural infrastructure is critical to the resilience of the urban environment, in that it provides many benefits related to storm protection, water and air purification, moderating urban heat effects, and socio-economics. South Florida's tourist economy is heavily dependent on these natural resources. The region must prioritize providing space for habitat transitions and focus on reducing anthropogenic pressures that would compound the degrading effects of sea level rise.

Id. at 10-11. 
and their partners to initiate planning to address the potential impacts of sea level rise on the region." ${ }^{148}$ In particular, it provides guidance to local governments about how they should use the report's different SLR projections ${ }^{\mathrm{I} 9}$ for different types of projects:

- The lower boundary of the projection ([the] dashed lined) can be applied in designing low risk projects that are easily replaceable with short design lives, are adaptable and have limited interdependencies with other infrastructure or services.

- The shaded zone between the IPCC AR5 RCP8.5 median curve and the USACE High is recommended to be generally applied to most projects within a short-term planning horizon. It reflects what the Work Group projects will be the most likely range of sea-level rise for the remainder of the 21st Century.

- The upper curve of the projection should be utilized for planning of high risk projects to be constructed after 2060 or projects which are not easily replaceable or removable, have a long design life (more than fifty years) or are critically interdependent with other infrastructure or services. ${ }^{150}$

The SLR Work Group concluded that "[o]ne of the values of this sea level rise projection is the ability to perform scenario testing to better understand the potential impacts and timeline of sea level rise within the Southeast Florida community." 151

148. Id. at 13 .

149. See infra Figure 1. The SLR Work Group recommended that "the unified sea-level rise projection include three curves, in descending order, the NOAA High Curve, the USACE High Curve and a curve corresponding to the median of the IPCC AR5 RCP8.5 scenario, with specific guidance as to how and when they should be used in planning," and that "this guidance be updated every five to seven years because of the ongoing advances in scientific knowledge related to global climate change and potential impacts." SEA LEVEL RISE WORK GRP., supra note 98 , at 1-2.

150. SEA LEVEL RISE WORK GRP., supra note 98 , at 4 .

151. Id. at 2; see also Butler et al., supra note 3, at 320 (noting that "ranges of estimated sea levels expand as SLR projections are extended into the future, furthering the substantial uncertainty with which adaptation planners must contend"). 
Figure $1^{152}$

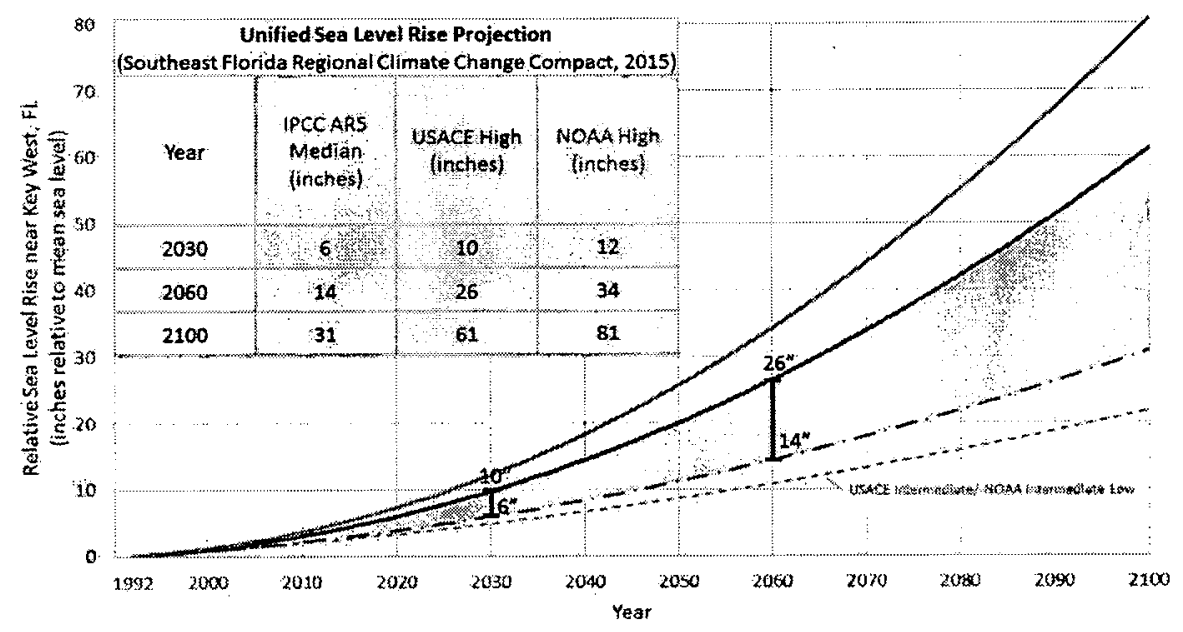

\section{Vulnerability Assessment (2012)}

In August 2012, the Compact produced a sea-level rise vulnerability assessment, entitled Analysis of the Vulnerability of Southeast Florida to Sea Level Rise. ${ }^{153}$ The assessment analyzes vulnerability to one-, two-, and three-foot SLR scenarios. The Compact's SLR projection is that the one-foot scenario will occur between 2040-2070, the two-foot scenario between 2060-2115, and

152. The SLR Work Group also provided the following clarification of its Unified Sea Level Rise Projection:

These projections are referenced to mean sea level at the Key West tide gauge. The projection includes three global curves adapted for regional application: the median of the IPCC AR5 RCP8.5 scenario as the lowest boundary ..., the USACE High curve as the upper boundary for the short term for use until 2060 . . ., and the NOAA High curve as the uppermost boundary for medium and long term use . . . The incorporated table lists the projection values at years 2030, 2060 and 2100. The USACE Intermediate or NOAA Intermediate Low curve is displayed on the figure for reference . . . This scenario would require significant reductions in greenhouse gas emissions in order to be plausible and does not reflect current emissions trends.

SEA LEVEL RISE WORK GRP., supra note 98, at 5.

153. Se. Fla. Reg'l Climate Change Compact inundation mapping \& Vulnerability ASSESSMENT WORK GRP., ANALYSIS OF THE VULNERABILITy OF SOUTHEAST FloRida TO SEA LEVEl Rise, at vi (2012) [hereinafter VULNERABILITY OF SOUTHEAST FloRIDA]. This assessment was based on the 2011 unified projection. Presumably it will be updated in light of the October 2015 updated unified projection. 
three-foot between 2075-2150. ${ }^{154}$ The vulnerability assessment found that all of the Compact Counties are vulnerable to sea-level rise, though degree of vulnerability varied by location. For example, "sixty-eight percent (44,885 acres) of unincorporated Monroe County's land mass is vulnerable with a one foot rise in sea level, while the percentage of the urban areas of Miami-Dade and Broward and the unincorporated area of Palm Beach is much lower." 155 The assessment unpacked vulnerability further as follows:

In terms of the critical infrastructure reviewed, inundation is often confined to marginal areas of the properties or impacting existing drainage infrastructure on site. This is generally true for the region's ports, airports, schools, landfills and hospitals. Monroe County is the exception with potential building and infrastructure inundation especially at the 2 and 3 foot sea level rise scenarios. Three of Monroe's four hospitals, $65 \%$ of their schools and $71 \%$ of their emergency shelters have property at elevations below sea level at the one foot scenario. Similar facilities in the other Compact Counties are mainly impacted at the 3 foot scenario. Power plants properties in Miami-Dade and Broward as well as energy transmission facilities in Monroe are vulnerable at the one foot scenario. While railroads are negligibly at risk, more than 81 miles of roadway from Miami-Dade through Palm Beach are at elevations below sea level at the one foot scenario, increasing to more than 893 miles at the three foot scenario. ${ }^{156}$

In terms of the dollar values of the infrastructure that is at risk, the vulnerability assessment summarized the situation as follows:

The upper estimate of taxable property values vulnerable across the region is greater than $\$ 4$ billion with values rising to over $\$ 31$ billion at the 3 foot scenario. The greater values reflected in the financial impacts are the low density and irregular residential properties proximate to the coast. ... [T] he roads that access these residential

154. Id. at vii. The analysis "is based on land and sea elevations only and does not consider flooding related to existing drainage issues, associated with rain events or that may be caused by tropical storm surge." Id. As noted above, presumably the vulnerability assessment will need to be updated in light of the recent updates to the SLR projection.

155. Id.; see also id. at 4.

156. Id. at vii. The analysis did not include impacts associated with sea-level rise that "require more complex modeling efforts, or indirect impacts, such as delineating what properties may become less accessible due to inundated roadways." RCAP, supra note 32 , at 10. 
areas are lower than the finish floor elevation of the homes and therefore subject to inundation prior to impacts to the homes. ${ }^{157}$

\section{Regional Climate Action Plan and Implementation Guide}

A third significant deliverable, developed in 2012, is a Regional Climate Action Plan ("RCAP"). ${ }^{158}$ The RCAP includes 110 recommendations to bolster resilience to sea-level rise and other climate change-related concerns. ${ }^{159}$ It was developed through a collaborative process that included "nearly 100 subject matter experts from a host of professions representing the public and private sectors, area universities, and not-for-profit organizations." 160 The goal was to "integrate climate adaptation and mitigation into existing decision-making systems and to develop a plan that can be implemented through existing local and regional agencies, processes and organizations."161

The Plan is intended to serve as a "framework to help guide policies and projects" but "emphasize [s] that [it] does not provide a mandate for any county or municipal actions, but rather serves as a living document with options that each regional or local government may adopt and utilize based on their interests and vision for the future."162 The Compact Staff Steering Committee has also issued a "Regional Climate Action Plan Implementation

157. VUlnERABILITY OF SOUTHEAST Florida, supra note 153, at vii; see also id. at 5-6. The assessment found that " $[\mathrm{n}]$ early $80 \%$ of the lands affected regionally in the one foot scenario are conservation lands especially coastal wetlands." Id. at 5 . It noted that because many of these areas have a conservation land use, "the financial value of these properties is minimally reflected in the taxable value of the properties. The true value of the impacts to these natural and conservation lands relative to their contribution to a healthy ecosystem, to qualify of life of our residents and to revenues associated with tourism are not captured here." Id.

158. See RCAP, supra note 32.

159. Id. at vi. The goal areas are: (1) sustainable communities and transportation planning; (2) water supply, management and infrastructure; (3) natural systems; (4) agriculture; (5) energy and fuel; (6) risk reduction and emergency management; and (7) outreach and public policy. Id. at 11 . The RCAP database enables some degree of review of progress. RCAP Dalabase, SE. Fla. Regional. Climate Change CompaCt, http://rcap. southeastfloridaclimatecompact.org [https://perma.cc/8KVG-3AEA] (last visited Sept. 22, 2016).

160. RCAP, supra note 32 , at v-vi.

161. Id. at vi.

162. Id. at 13. 
Guide," which is intended to provide further guidance on how the 110 recommendations in the Plan can be "put to work." 163

\section{Collaborations on Legislative Policy}

The Compact also committed the counties to collaborate on legislative policy. ${ }^{161}$ Each year, the Compact prepares a legislative program for the Florida legislature that all four county commissions approve. ${ }^{165}$ The AAA legislation adopted at the State level was the result, at least in part, of the Compact's support for such an initiative. ${ }^{166}$ As the counties' RCAP summarizes:

Utilizing the Compact Counties' Legislative Programs as guidance during the 2011 Florida Legislative Session, the Compact Counties were successful in helping to amend state law to reflect priority policy goals. The regional partners helped draft and led efforts to provide for a designation of "Adaptation Action Areas" in Florida's growth management laws, thus creating a new tool for local governments to identify areas vulnerable to coastal flooding resulting from the impacts of sea level rise and to prioritize infrastructure improvements and funding for improved resilience. ${ }^{167}$

For the most recent State legislative session, in 2016, the Compact state legislative priorities included support for SB 584,

163. Id; Se. Fla. Reg'l Compact Ctys., Regional Climate Action Framework: IMPLEMENTATION GUIDE (2014). For each recommendation in the RCAP, the guide provides a proposed time frame for planning, a list of potential partners, a list of potential funding sources, whether policy and/or legislation is needed, estimated resources (e.g., existing staff or others), and milestones for assessing progress.

164. RCAP, supra note 32, at 3. Compact Resolution Sections 1-4 incorporate a commitment by each county to work together to develop joint policy positions at the federal and state levels.

165. E-mail from Janet E. Bowman, supra note 64.

166. GCC CASE STUdIES, supra note 3, at 1,8 (noting that " $[\mathrm{t}]$ hrough the Compact, the counties were successful in getting [the AAA] legislation passed"; that " $t$ ] he Compact's work to inform policy spurred the passage of state legislation enabling consideration of sea-level rise in comprehensive plans"; and that the Compact's Policy Work Group "drafted legislative language for AAAs that formed the basis for the bill").

167. RCAP, supra note 32, at 4 (discussing the submission of a "joint Climate Adaptation Pilot Project Proposal" to Congress that would seek funds to support regional hydrologic modeling, among other joint proposals). The Compact Counties adopted 2011 and 2012 Southeast Florida State and Federal Energy and Climate Legislative Programs, which they used to advocate before Congress and the Florida legislature. Id. at 4. The RCAP authors assert that it is "realistic to believe that future funding opportunities will become available through federal and state appropriations and grants for [AAAs] or areas similarly designated for adaptation planning." Id. at 14 . 
which, as noted above, would have authorized the State to create a $\$ 50$ million matching fund for local government flood risk reduction projects. ${ }^{168}$

In sum, in addition to convening annual summits as a way to bring people together and build support, ${ }^{169}$ the Compact has completed several efforts during its first five years of existence. It has now developed two rounds of sea level projections, an initial effort in 2011 and a second round in 2015. Following the 2011 projection of sea level rise, the Compact also developed a vulnerability assessment in order to highlight vulnerability to sea level rise. A third step was development of detailed guidance, including a guidebook, to help local governments consider and implement possible actions to address sea-level rise. Beyond these actions, the Compact has also extended its reach at least to the State capitol, where the legislature adopted the AAA legislation in 2011 due in part to the urging of the Compact and its member communities. ${ }^{170}$ More broadly, the Compact has developed a unified policy agenda to guide its interactions at the state and federal levels. ${ }^{171}$

\section{FLORIDA'S REFORMS AND INNOVATIONS IN CONTEXT}

Attention to adaptation issues relating to sea-level rise and other consequences of climate change has increased dramatically in recent years, after what many have characterized as a belated start. ${ }^{172}$ Because of its extensive coastline, its topography, and the

168. See supra note 71 and accompanying text. As noted above, the legislature did not enact SB 584 during the 2016 session.

169. The Summit, Se. Fla. Regional Climate Change CompaCt, http://www.southeast floridaclimatecompact.org/the-summit [https://perma.cc/3HCT-PLB9] (last visited Jan. 3, 2016).

170. See RCAP, supra note 32 , at 4 .

171. See id.

172. See supra notes 8-11 and accompanying text. For examples of federal attention, see, for example, Exec. Order No. 13,514, 74 Fed. Reg. 52,117 (Oct. 5, 2009) (titled "Federal Leadership in Environmental, Energy, and Economic Performance"); Exec. Order No. 13,653, 78 Fed. Reg. 66,819 (Nov. 1, 2013) (titled "Preparing the United States for the Impacts of Climate Change"); Exec. Order No. 13,690, 80 Fed. Reg. 6425 (Jan. 30, 2015) (titled "Establishing a Federal Flood Risk Management Standard and a Process for Further Soliciting and Considering Stakeholder Input"); see also ANNE SIDERS, MANAGED COASTAL

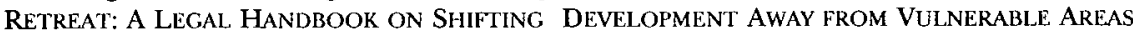
(2013); Jessica Wentz, Assessing the impacts of Climate Change on the Built ENVIRONMENT UNDER NEPA ANd STATE EIA LAWS: A Survey of Current PraCtices AND RECOMMENDATIONS FOR MODEL PROTOCOLS (2015); Ray \& Grannis, supra note 2. 
concentration of much of its population and economic activity along the coasts, Florida is in the crosshairs in terms of possible impacts from sea-level rise in particular. ${ }^{173}$ The three initiatives discussed in this Article provide the grist for several observations about the response to increasing risks from sea-level rise. This Part of the Article suggests two frames of reference for considering these initiatives: a focus on key actors engaged in adaptation to sealevel rise in Florida, and the concepts of adaptive governance and adaptive management. ${ }^{174}$

\section{A. The Key Actors}

One issue that has surfaced in the legal scholarship concerning the response to SLR and other impacts of climate change involves the roles that different actors should play. ${ }^{175}$ Parts II-IV above

173. See Fla. Dep't of Envtl. Prot., Climate Change and Sea LeVel Rise in Florida, at 8 (2010) (reporting that "much of the state is low, relative to sea level, and flat"); Florida Geological Survey-Coastal Research Projects, Fla. DEPT. OF ENVTL. Protection, http://www.dep.state.fl.us/geology/programs/coastal/coastal.htm [https://perma.cc/ UZU7-XX7M] (last updated Nov. 10, 2014) (noting that the State has more than 1260 miles of coastline). For a recent assessment of the risks in Southeast Florida, see VULNERABILITY OF SOUTHEAST Florida, supra note 153; see also STATES AT RISK, NATIONAL SUMMARY 14 (2015), http://assets.statesatrisk.org/media/NationalSummary.pdf [https://perma.cc/8TZDNZUT] (asserting that Florida, along with Louisiana, "face[s] enormous coastal flooding risks, far greater than any of the other 22 coastal states"); Butler et. al., supra note 3 , at 320 (stating that "Florida, particularly South Florida, is at the apex of vulnerability in the United States to slow inundation from SLR and acute flooding and erosion associated with storm surges exacerbated by SLR").

174. It is not the purpose of this Article to evaluate the adequacy of the SLR response to date. For an early assessment, see Butler et al., supra note 3; see also RUPPERT \& STEWART, supra note 3 , at 3 (concluding that because of Florida's vulnerability one might have assumed that the State was in the forefront, and that while this had "not been the case," "much of this may be set to change" because of the 2015 legislation). There have been other efforts in the State not considered here. See, e.g., S. 888, 2006 Leg. (Fla. 2006) (creating the Florida Energy Commission); Fla. Exec. Order No. 07-128 (July 13, 2007) (directing development of an Energy and Climate Change Action Plan). See generally Deady \& Ruppert, supra note 4 (providing an overview of actions in Florida).

175. See Carlson, supra note 8 (addressing certain differences in the proper roles of federal and state governments with regard to climate change initiatives); Chaffin et al., supra note 8 (discussing adaptive governance theory and the roles of multiple actors and levels of governance); Engel, supra note 8 (discussing this issue in the context of the democratic experimentalism and federalism literatures); Kaswan, supra note 8 , at 397 (explaining that "although not all the arguments for a federal role in land use are unique to climate change, climate change poses challenges that require a new look at accepted norms of local control"); see also NOLON, supra note 10, at 221 (noting that a significant challenge is "how to integrate land use decision making-a role generally assigned to local governments under our federal system-with state and federal environmental initiatives"); supra Part I. 
reflect that the fulcrum for action, particularly concerning the comprehensive planning mechanism that is the focus of much of the paper, lies at the local government level. ${ }^{176}$ State law articulates, as an important purpose, enhancing the power of local governments to use their comprehensive planning authorities to govern future land use in their respective jurisdictions. ${ }^{177}$ The 2011 legislation's creation of the new, entirely optional, AAA tool for local governments is consistent with this overall direction. ${ }^{178}$ The 2015 State legislation's imposition of a new mandate on local governments to plan for flood risks based on anticipated sea-level rise and other factors signals a ratcheting up of State concern. ${ }^{179}$ While the legislation includes opportunities for engagement by non-local government actors, it nevertheless appears to leave much of the responsibility for action to local governments. ${ }^{180}$ And even though the Southeast Compact represents the "first example where U.S. counties voluntarily committed to work at the regional scale to adapt to climate change impacts," 181 the Compact's intended function is to enhance the capacity of local governments, not to displace them. ${ }^{182}$

176. See supra Parts II-IV; see also CARMIN ET AL., supra note 12, at 2 (concluding more generally, beyond Florida and its comprehensive planning mechanism, that "the commitment of local officials is essential to advancing adaptation planning and implementation"); NoLON, supra note 10, at 221 (discussing the important but limited role of comprehensive planning).

177. FLA. STAT. $\$ 163.3161$ (2) (2016) (providing that " $[\mathrm{i}] \mathrm{t}$ is the purpose of this act to utilize and strengthen the existing role, processes, and powers of local governments in the establishment and implementation of comprehensive planning programs to guide and manage future development consistent with the proper role of local government"). The roles of different levels of government have shifted over the years. Nancy Stroud, A History and New Turns in Florida's Growth Management Reform, 45 J. MARSHALL L. REV. 397, 397, 411, 414 (2012) (reviewing the evolution of Florida's system of land use regulation; finding that recent amendments have "significantly reduce[d] the state and regional management components of the [State's integrated] system"; elaborating on the decreased state and regional roles; and concluding that "Florida's long experiment with The Quiet Revolution has entered a new stage which is still too recent to fully appreciate").

178. SFRPC GUIDEBOOK, supra note 34, at 64-65 (asserting that the 2011 Community Planning Act provides "great latitude" to local governments regarding the content of a comprehensive plan and how they address the issues covered in a plan).

179. See generally Deady \& Ruppert, supra note 4.

180. Id. at 10; see also supra Part III.

181. See GCC CASE STUDIES, supra note 3 , at 1 .

182. RCAP, supra note 32 , at 13 ("emphasiz[ing]" that the Compact "does not provide a mandate for any county or municipal actions, but rather serves as a living document with options that each regional or local government may adopt and utilize based on their interests and vision for the future"); SURVEY REPORT, supra note 3 , at 3 (noting that the 
It would be overly simplistic, and incomplete, however, to leave the analysis of actors at that. ${ }^{183}$ In at least one respect, the previous paragraph understates the importance of local governments in the formulation and implementation of policy relating to SLR. The important role that the Southeast Compact local governments played as catalysts in enactment of the 2011 legislation is an example of the influence that local governments have at the state and federal levels, well beyond their geographic boundaries. ${ }^{184}$

Further, assessments of the current and future roles of different actors should account for the reality that, as summarized above, actors other than non-local governments have actively contributed to efforts in Florida to address SLR and related impacts and will undoubtedly continue to participate, with roles evolving over time. ${ }^{185}$ For example, the State legislation discussed above builds in opportunities for participation by the State as well as by NGOs and other non-local government actors. ${ }^{186}$ The Article explores some of the issues that are likely to affect the level and nature of such participation. ${ }^{187}$

The innovative Southeast Compact represents a significant effort to engage a wide array of stakeholders. The Compact began as an experiment in horizontal coordination among counties, with one purpose being to bolster prospects for obtaining support from the federal government. ${ }^{188}$ The Compact's progress has been

Compact is "designed to enable local governments to set the agenda for climate change solutions"); see also GCC CASE STUDIES, supra note 3, at 4 (noting that the Compact is "not a formally recognized legal entity" and "has no official legal status"; that as a result, the Compact "has no legal authority" and Compact actions "have no legal effect"; that instead, the Compact relies on the powers of its constituent counties, and municipalities and Compact recommendations must be adopted by county and municipal governments; and that similarly, the Compact has "no dedicated source of funding and no means by which to take in grants or other sources of funding"-rather, "grants must be funneled through individual local government members of the Compact, or through [the ISC]").

183. See supra note 175 and accompanying text.

184. See supra notes 27-32. For an example of an effort to obtain local input to support development of federal policy, see, for example, Exec. Order No. 13,653, 78 Fed. Reg. 66,819 (Nov. 1, 2013) (creating a State, Local, and Tribal Leaders Task Force on Climate Preparedness and Resilience in order "inform Federal efforts"); see also Davidson, supra note 8 , at $\mathbf{n} .25$ (noting that "[a]n extensive body of political science research has documented the practice not only of local adaptation of federal resources but also of the initiative that local governments take in shaping federal policy").

185. See supra Part I.

186. See supra Parts II-III; see also RCAP, supra note 32, at 4-5.

187. See generally supra Parts II-III.

188. See RCAP, supra note 32 , at 1,3 . 
supported by "a variety of local, regional, state, and federal agencies (NOAA, USACE, USGS [U.S. Geological Survey], and USEPA), as well as myriad stakeholders." ${ }^{189}$ The coordinated efforts of a wide range of local, regional, state, and federal officials, as well as non-government participants such as academics and environmental groups, have contributed to the development of several of the Compact's work products. ${ }^{190}$ Significant amounts of funding for the work that has been done to date under the auspices of the Compact have come from outside sources, including the Kresge Foundation's grant and NOAA's financial support for the five-year DEO community resiliency project, which has funded considerable work, including the SFRPC's Guidebook. ${ }^{191}$ In short, the Compact's experience qualifies as an experiment in what some scholars have referred to as "multilevel governance," ${ }^{192}$ and others as "new governance." 193 The experience of the Compact in engendering such cooperation, including its successes as well as any failures, offer fertile soil for further study.

189. SURVEY REPORT, supra note 3 , at 3 (also noting that a purpose of the regional model is "to ... provid[e] an efficient means to coordinate federal and state engagement"); Jody Freeman \& Jim Rossi, Agency Coordinalion in Shared Regulalory Space, 125 HARv. L. REv. 1131 (2012) (discussing issues of coordination).

190. See SEA LeVEl RISE WORK GRP., supra note 98, app. D at 34 (providing a list of the SLR Work Group participants).

191. See supra note 138 and accompanying text; SFRPC GUIDEBOOK, supra note 34 , at 1 .

192. Inger Weibust, Introduction, in MULITLEVEL ENVIRONMENTAL GOVERNANCE: managing Water and Climate Change in Europe and North America 4-5 (Inger Weibust \& James Meadowcroft eds., 2014) (offering multiple definitions of multilevel governance, including a "term for governance in federal systems that goes beyond the usual two levels [federal and state governments] that define federal systems"). Other labels are used as well. See, e.g., Chaffin et al., supra note 8 (discussing adaptive governance and noting that it includes a "range of interactions between actors, networks, organizations, and institutions" and also that it involves multilevel governance); Engel, supra note 8 (discussing democratic experimentalism).

193. Engagement of NGOs is a common theme in the "new governance" literature. See, e.g., Neil Gunningham, The New Collaborative Environmental Governance: The Localization of Regulation, 36 J.L. \& SoC'Y 145, 146-50 (2009) (discussing "new governance"); Orly Lobel, The Renew Deal: The Fall of Regulation and the Rise of Governance in Conlemporary Legal Thought, 89 MiNN. L. REV. 342, 348 (2004) (discussing features of a "new governance" model as including "increased participation of nonstate actors"). Other theories of governance cover this landscape as well. See e.g., Engel, supra note 8, at 2 (characterizing democratic experimentalism as a theory of governance that "locates policymaking authority at the local level," has the central authority operating primarily to support local governments, and features a central authority that includes private and non-profit sector representatives). 
In addition to reviewing some of the Compact's accomplishments, including several discussed above, ${ }^{194}$ it is also worthwhile to flag at least two potential concerns about the Compact as a possible governance model that relate to fundamental questions of policy design. The first, which relates to the multilevel governance character of the Compact, involves the question of municipal integration into the Compact-specifically, the level of municipal buy-in. At least two pieces of data raise questions concerning efforts to attract municipal support and buyin for the Compact. Only about one fourth of the mayors of municipalities located within the geographic area of the Compact have signed the Mayors' Climate Action Pledge. ${ }^{195}$ Further, as indicated above, only fifty-five municipalities $(51 \%)$ of Southeast Florida participated in the 2014 survey that ISC conducted to evaluate progress in implementing RCAP recommendations. ${ }^{196}$ The relatively limited municipal role in the Compact's decisionmaking process would seem to be one of the features of the Compact that deserves attention. ${ }^{197}$

The second structural feature of the Compact that the Article highlights in this Part relates to funding-notably, the Compact's inability to raise funds directly and its reliance, therefore, on funding from other sources. As the Georgetown Climate Center observes, the Compact has "no dedicated source of funding and no means by which to take in grants or other sources of funding .... $[\mathrm{G}]$ rants must be funneled through individual local government

194. See supra Part IV.

195. There are 108 municipalities in Southeast Florida and, as of this Article's writing, thirty municipalities have signed the Action Pledge. SURVEY REPORT, supra note 3, at 5; Mayors' Climate Action Pledge-Signing Cities, Se. Fla. Regional Climate Change Compact, http://www.southeastfloridaclimatecompact.org/mayors-climate-action-pledge-signing-cities [https://perma.cc/WCX5-XL7U] (last visited Nov. 26, 2016).

196. See SURVEY REPORT, supra note 3, at 5. The ISC characterized this response rate in a positive way, noting that "[d] espite having less than a month to complete the project, the relatively high success rate is a result of contacting $81 \%$ of municipalities via telephone to remind them to complete the survey and emailing the survey to $99.1 \%$ of municipalities." Id.

197. Each of the counties participating in the Compact has full voting rights in participating in directing the Compact's activities, and the Compact Counties collectively control the outcome of Compact deliberations because of the voting process adopted (only four of the twelve voting positions are held by municipalities). Municipalities obviously have much less say, and only four of the 108 municipalities in the Compact's geographic jurisdiction have a formal voice at all. Issues relating to local government institutional structure, operations, coordination, and capacity are beyond the scope of this Article. See generally Briffault, supra note 8 . 
members of the Compact, or through [the ISC]." 198 This feature of the Compact's structure raises questions about the sources and reliability of the funding the Compact needs to succeed. The Kresge Foundation grant of close to $\$ 1$ million to support ISC's engagement has provided a substantial capacity boost to the Compact. As noted above, the Compact's 2014 Municipal Implementation Survey Report characterizes the ISC as a "partner" with the Compact in developing a "regional climate governance model." 199 What would be the consequences for the Compact (at its inception, or more recently) if outside funding from NGOs were not forthcoming? What will be the consequences if such funding dries up? Reliance on such funding has possible implications for the sustainability and future prospects of the Compact itself, and for the prospects of initiatives elsewhere that seek to replicate the Compact model, that deserve close attention. ${ }^{200}$

In a recent article, this author and Professor Robert Glicksman highlight the importance of considering the roles of the entire suite of potential actors as part of policy design. ${ }^{201}$ Professor William Buzbee has noted that, as a general matter, "[t]he optimal mix of federal, state, and local regulatory roles... inevitably changes over time as technological, environmental, market, and political changes occur." ${ }^{202}$ Some scholars have already begun to suggest that the roles of different actors will need to change

198. GCC CASE STUdies, supra note 3 , at 4 .

199. SURVEY REPORT, supra note 3, at 3; see also supra notes 139-140. For example, the ISC also administered the survey that formed the basis for the 2014 report. SURVEY REPORT, supra note 3 , at 4 .

200. This Article's objective is to highlight the importance of following the money trail for innovative governance structures. This Article does not take a normative position concerning the desirability of any particular funding approach. One question involves whether existing Florida laws provide institutional structure options that are worth considering. See, e.g., FLA. STAT. $\S 163.01$ (2016) (providing for interlocal agreements). For a review of the funding of interstate environment and natural resource compacts, see U.S. Gov't ACCOUNTABILITy OfFICE, GAO-07-519, INTERSTATE COMPACTS: AN OVERview of THE STRUCTURE AND GOVERNANCE OF ENVIRONMENT AND NATURAL RESOURCE COMPACTS, at 2 (2007) (discussing types of authority compacts possess and the roles of commissions in administering the compacts, and finding that many compacts are funded, "in whole or in part, by the member states"). Especially given the concerns that some have raised about possible NGO influence through funding, project design of ventures that are likely to be reliant on such funding should be particularly sensitive to such concerns. See generally Mark Seidenfeld, Empowering Stakeholders: Limits on Collaboration as the Basis for Flexible Regulation, 41 WM. \& MARY L. REV. 411 (2000) (highlighting issues concerning the motivations of NGOs).

201. Markell \& Glicksman, supra note 8.

202. Buzbee, supra note 8 , at 94 . 
dramatically because of the challenges that climate change poses. ${ }^{203}$ Particularly as more information emerges regarding vulnerability to SLR and related impacts, and regarding the efficacy of efforts to address such impacts, it will be important to assess the roles that different actors are playing, whether changes in responsibility and capacity, among others, are warranted, and if so, what they might be and how to achieve them. In its review of the roles of different actors in the three Florida initiatives discussed above, this Article identifies some of the outstanding questions concerning the likely prospects for these initiatives when viewed through this frame. ${ }^{204}$

\section{B. "Adaptive Governance" and "Adaptive Management"}

A second critical governance question, related to the issue of allocation of responsibilities discussed in the preceding section, involves the governance structure that society should use to identify and address public policy challenges such as SLR. Because of the dynamic character of SLR and other aspects of climate change"predictability is elusive"-scholars in several disciplines have suggested that "[a]ssumptions of stationarity are eroding." ${ }^{205}$ They

203. See Chaffin et al., supra note 8 ("An implicit assumption in our definition of AG [adaptive governance] is that a shift in governance toward $A G$... will only occur when the current state of an SES [social and ecological system] is undesirable, untenable, or both, e.g., loss of important ecosystem function such as filtration, pollination, flood abatement, or social conflict over the management of scarce resources."); see also supra notes 8-11; cf. Katherine A. Trisolini, All Hands on Deck: Local Governmenls and the Potenlial for Bidirectional Climale Change Regulation, 62 STAN. L. REv. 669, 677, 740 (2010) (emphasizing the role that local governments can play in a "multilevel ... approach to climate change," and discussing barriers to displacing local power in the land use area, among others, in the context of mitigation).

204. See supra notes 8-11, 175. Framed in the context of adaptive governance, discussed below, the discussion in the text offers a starting point for thinking in more depth about issues such as how adaptive governance emerges, and how adaptive governance is institutionalized.

205. Roert E. Deyle \& William H. Butler, Resilience Planning in the Face of Uncertainty: Adapling to Climale Change Effects on Coastal Hazards, in DISASTER RESILIENCY: INTERdisciplinARY Perspectives 178-79 (Naim Kapucu et al. eds., 2013) ("Scholars have begun to understand that stability is an elusive state for complex socio-ecological systems that are subject to periodic acute perturbations, such as natural hazards and economic shocks, and slow-moving chronic changes, such as shifting demographic patterns and climate change which repeatedly and continuously alter system conditions and dynamics."); P.C.D. Milly et al., Stationarity Is Dead: Whither Water Management?, 319 SCIENCE 573, 573 (2008) (describing "stationarity" as "the idea that natural systems fluctuate within an unchanging envelope of variability," and concluding that, because of climate change, "stationarity is dead"). 
have suggested that environmental governance "must be[come] highly adaptive" "because of the[se] uncertainties." 206

"Adaptive governance" and "adaptive management" have been championed as frameworks that will bolster adaptability, and thereby facilitate greater resilience to SLR and other changes in climate. ${ }^{207}$ Adaptive governance refers to the "social contexts that facilitate adaptive management." ${ }^{208}$ It "indicates[s] "the type of governance necessary to allow sufficient flexibility for adaptive management." ${ }^{209}$ To the extent that adaptive management has proven "difficult to implement because of the complex political nature of carrying out experiments with the goal of adjusting policy in response to monitoring results," 110 the hope is that adaptive governance will help to overcome barriers to identifying and implementing needed policy adjustments.

206. Chaffin et al., supra note 8 (indicating that adaptive governance is "firmly situated ... in the context of resilience scholarship," which "shifts the role of governance institutions and organizations from limiting change to managing and shaping the ability of a system to copy with, adapt to, and allow for further change").

207. Professor Ruhl has noted that scholars have considered adaptive capacity and resilience in the context of climate change in a range of disciplines and "recently have begun to consider how these [concepts] might inform the design of laws." He suggests that the focus of legal scholars has largely been on how law "can facilitate making the socialecological system resilient." Ruhl, supra note 11, at 1374, 1384 (suggesting that "[t]hese two properties - resilience and adaptive capacity - have become central themes for researchers studying a wide array of ecological, social-ecological, and social systems under the banner of resilience theory"); see also Brian Walker et al., Resilience, Adaplability and Transformability in Social-Ecological Systems, 9 ECOLOGY \& SOC'Y 5 (2004) (defining adaptability as "the capacity of humans to manage resilience" and adaptive governance as "a process of creating adaptability and transformability"). Walker et al. suggest that there may be a tension, as well as an overlap, between "maintaining the resilience" of a system and "simultaneously building a capacity of transformability, should it be needed."

208. There are multiple conceptions of adaptive governance. See Chaffin et al., supra note 8 (pointing out that, while the use of the term "adaptive governance" has grown significantly, "consistent use of the term and an explicit research agenda have not yet coalesced"; and further noting that while adaptive governance can be "broadly defined as ... [a] range of interactions between actors, networks, organizations, and institutions emerging in pursuit of a desired state for social-ecological systems," there is a normative element of this definition in light of its objective of achieving a "desired state" for social-ecological systems, and that this definition does not answer outstanding questions concerning "who and what sets of values determine the desired state, in both ecological and social terms"); Cosens et al., The Role of Law in Adaptive Governance, ECOLOGY \& SOC'Y (forthcoming) (suggesting an expanded definition of adaptive governance that acknowledges the value of approaches other than adaptive management). For a helpful synthesis of the adaptive governance scholarship that discusses adaptive governance, adaptive management, and various literatures that relate to each, see Chaffin et al., supra note 8.

209. Chaffin et al., supra note 8 .

210. Id. 
A goal of an adaptive management approach to governance is "to reduce uncertainty through integrative learning fostered in a structured, iterative decisionmaking process." ${ }^{211}$ Butler et al., in their review of adaptation work in Florida, identify three elements of an "ideal approach" to adaptation in the context of SLR in Florida that is based in part on "iterative adaptive risk management."212 Communities should assess their vulnerability. They then should choose adaptation actions that will promote resilience by minimizing risks associated with such vulnerability. And, third, communities should operate iteratively by monitoring and evaluating the rate of SLR, the impacts of accelerating SLR, and the effectiveness of the strategies being used. ${ }^{213}$

How do things look in connection with the implementation of these three stages of adaptive management? One answer, as suggested above, is that there is a significant knowledge deficit, so information is sparse. As a backdrop to their survey of Florida communities' adaptation efforts, Butler et al. suggest that a lack of foundational information exists nationally in understanding and

211. Robin Kundis Craig \& J.B. Ruhl, Designing Administrative Lau for Adaptive Management, 67 VAND. L. REV. 1, 20 (2014). Craig and Ruhl elaborate as follows on the concept:

The idea of adaptive management is that ... the timing of ... decisions is spread out into a continuous process that makes differentiating between the "front end" and the "back end" of decisionmaking much less relevant. Rather than make one grand decision and move on, agencies employing adaptive management engage in a program of iterative decisionmaking following a structured, multistep protocol: (1) definition of the problem, (2) determination of goals and objectives for management, (3) determination of the baseline, (4) development of conceptual models, (5) selection of future actions, (6) implementation and management actions, (7) monitoring, and (8) evaluation and return to step (1)... With deep roots in natural resources management theory, the adaptive management protocol has begun to make inroads in public lands management in particular, though it has been applied or proposed in other policy contexts, including pollution control, financial regulation, environmental impact assessment, public health and safety, civil rights, and social welfare.

Id. at 7-8. Enhancing resilience is a related notion in the literature. See Neil Adger et al., Social-Ecological Resilience to Coastal Disasters, 309 SCI. 1036, 1036 (2005) (defining resilience as involving "the degree to which [a] system can build capacity for learning and adaptation"); Walker et al, supra note 207 (defining resilience as "the capacity of a system to absorb disturbance and reorganize while undergoing change so as to still retain essentially the same function, structure, identity, and feedbacks").

212. Butler et al., supra note 3 , at 321 (indicating that this ideal approach drew from "the paradigms of rational comprehensive planning, hazard mitigation planning, resiliency, and adaptive management").

213. Id. at 321-22. There are many descriptions of adaptive management with a variety of typologies. See e.g., Craig \& Ruhl, supra note 211. 
tracking the adaptation activity that is occurring or on the drawing board at each of these three stages: "published studies provide little insight into the quality and rigor of vulnerability assessments, the specific adaptation strategies deployed, or the extent to which communities have committed to monitoring and evaluating the efficacy of their initiatives or the effects of ongoing climate change."214

In their evaluation of Florida communities' efforts to respond to SLR, Butler et al. found significant variations in community responses for each of the three elements of their ideal approach. ${ }^{215}$

214. Butler et al., supra note 3, at 322. Other observers have reached the same conclusion. See e.g., Ray \& Grannis, supra note 2, at 22-23 (noting that, while Georgetown catalogues local adaptation plans, it has not yet begun to track their implementation; asserting that " $[t]$ o gain a full understanding of our progress in preparing for climate impacts, we need research into the progress localities are making in implementing their adaptation plans"; and concluding that "it is difficult to assess the progress states, localities, and federal agencies are making in actually reducing vulnerability to climate impacts," and that researchers "lack sufficient understanding of the efficacy of [adaptation] actions"); see also CARMIN ET AL., supra note 12, at 1, 14, 16, 25 (noting the "nascent state of planning initiatives" by the cities that participated in the Global Survey). Developing a more full understanding of actions and results is likely to present a wide range of issues, including methodological questions. Developing metrics for performance, in addition to activities, will be challenging. See Debra Kahn, Calif. Refines its Definition of 'Resiliency', ClimateWire, Mar. 29, 2016, http://www.calclimateag.org/wp-content/uploads/2016/03/Calif.-refines-itsdefinition-of-resiliency-Climate-Wire-3-29-16.pdf [https://perma.cc/5DXK-MHRQ] (quoting J.R. DeLaRosa, assistant secretary for climate change for the State of California's Natural Resources Agency, as stating that “[n]o one in the world has come up with a metric system for measuring resiliency" reporting; noting that the State of California is in the early stages of evaluating its options for promoting adaptation and resilience; concluding that while California "has been aggressive in establishing" mandates to mitigate climate change by limiting emissions of greenhouse gases, "when it comes to adaptation, the state is so far using soft power: setting guidelines and using state funding as an incentive to encourage climatecognizant decisions"; and quoting California Assemblyman Rich Gordon, one of the state's "biggest champions of adaptation," as conceding that it may not be possible for California to "mandate adaptation in the way in the way that we've been able to mandate mitigation, but ... we will need to find ways to incentivize people to engage in additional adaptation"); see also supra notes 8-11, 172, 175 (more generally discussing the nascent stage of adaptation work and, more specifically, the extremely limited grasp researchers have of the work that is ongoing or the results it is producing).

215 Butler et al., supra note 3, at 319-29 (explaining their methodology and noting that Florida currently has a knowledge deficit as well). The Butler et al. case study, the ISC survey, and the Ruppert and Stewart survey, all discussed in this Article, are helping to build such a knowledge base and one of the purposes of this Article is to contribute to that effort.

Other studies suggest, unsurprisingly, that progress elsewhere is also uneven. CARMIN ET AL., supra note 12, at 1, 14, 16 (finding that cities internationally are in various preparatory stages of adaptation planning and take different approaches to adaptation planning). In addition to differences in vulnerability and perceived vulnerability, as Professor Briffault explains, there is "enormous variety" of local governments in terms of their size, fiscal 
They found that, while "[n] early all of the local governments in [the] sample (98 percent) have access to some SLR hazard assessment intelligence," some assessments "provide no more than minimalist descriptions of expected SLR impacts," while others "are more comprehensive, identifying specific assets likely to be flooded and tabulating the numbers of people, total property value, and measures of different critical facilities likely to be exposed to flooding."216 Similarly, the adaptation actions that communities are undertaking, or have committed to undertake, also vary significantly. Forty-three percent of the coastal communities in their sample "have not committed to any land use adaptation actions"; of the remaining $57 \%$, the commitments "vary greatly in terms of commitment." 217 Finally, approaches to monitoring and evaluation vary significantly as well. ${ }^{218}$ In short, Butler et al. found that communities in Florida have "moved to different points along a continuum of SLR adaptive planning initiatives."

capacity, needs, and politics. Briffault, supra note 8, at 2; Richard Briffault, Our Localism: Part II-Localism and Legal Theory, 90 CoLum. L. Rev. 346, 349-52 (1990) (reviewing the significant differences between and among municipalities and discussing the lack of capacity of some municipalities to meet their needs).

216. Butler et al., supra note 3 , at 324 (elaborating that $21 \%$ of the communities the authors investigated "only have access to hazard identification information, with no specific descriptions of likely impacts," and that one such community "simply acknowledges SLR as a hazard in its comprehensive plan").

217. Id; see also id. at 327,329-30 (finding that "[m]ost of the coastal communities in Florida we observed have demonstrated a predilection for cautious, low-regrets, incrementalism"). As Butler et al, detail, accommodation "predominates" for communities that have committed to "considering or implementing conventional SLR adaptation strategies," while a smaller number of communities have committed to "protection" approaches (primarily shoreline armoring) and avoidance approaches (which primarily qualify as "equivocal" in that they simply call for taking SLR into account). Id. at 326. Butler et al. define "low-regrets" approaches as risk reduction strategies rather than risk elimination approaches. Id. at 321 (explaining that "[1]ow-regrets measures require relatively small short-term investments for relatively large anticipated climate adaptation benefits").

218. Id. at 328 (also finding that "no community in our review has explicitly committed to evaluating the performance or efficacy of their adaptation strategies," and that "[a]s such, they are overlooking a key aspect of monitoring suggested by an iterative adaptive risk management framework").

219. Id. at 319-29 (also reviewing different local governments' efforts). As the discussion above reflects concerning the 2011 and 2015 legislation, while a few local governments have begun to implement one or both pieces of legislation, many have not. See supra Sections II.B.2, III.B. In their survey, Ruppert and Stewart similarly find very different approaches in "mention[ing]" or "address[ing]" SLR in different communities' comprehensive plans. See RUPPERT \& STEWART, supra note 3, at 4, 6, 39 (noting that some communities "stand out" for their responses to SLR). The Southeast Compact Survey similarly found very different levels of preparation. See SURVEY REPORT, supra note 3. 
Despite the limited information available, and the uneven character of adaptation efforts in Florida, Butler et al. offer a series of findings about the state of adaptation efforts by local governments in Florida. First, they suggest that some of Florida's coastal communities are ahead of the national curve: "Some of the Florida coastal communities we have studied appear to have made more significant progress toward adapting to accelerating SLR impacts than that reported in other recent studies of climate change adaptation where most communities have not moved beyond the vulnerability assessment stage." 220 They suggest that "[ $\mathrm{t}]$ his may reflect somewhat lower uncertainty about SLR as one of the most straightforward consequences of a warming climate. Florida has clear trend data from robust sources [showing SLR], although scientists and officials are still uncertain about the rate of acceleration."221 Further, SLR may have higher salience in areas that are "already experiencing impacts attributed to accelerating SLR: rapidly advancing saltwater intrusion into water supply aquifers, sunny day king tide street flooding, and recurring damage to infrastructure from coastal storms of modest intensity." ${ }^{222}$ More generally, Butler et al. suggest that the increasing salience of the risks associated with SLR may help to explain the variations in preparedness and, in particular, why some communities in Florida have been more proactive than others: "as the nature of SLR hazards becomes clearer and more urgent, communities generally move along a continuum of commitment from no action to adopting legally enforceable policies and regulations and making capital investments to reduce risks to urban assets." 223

220. Butler et al., supra note 3, at 329; see also id. at 327 (noting that "we found that more than one-third (36 percent) of the coastal communities we examined have adopted one or more enforceable comprehensive plan policies or land development regulations or committed to specific adaptation actions through capital improvement plans or projects").

221. Id. at 329 .

222. Id.

223. Id. at 327. The authors suggest various reasons for such variation, including communities' differing “tolerance for trade-offs between over-and under-adapting, their experience with SLR related impacts, and the availability of credible planning intelligence in the face of substantial uncertainty." Id at 319 . The authors also note that "[c]redible planning intelligence about future sea level elevations and associated impacts appears to comprise an important foundation for adopting SLR adaptation initiatives in most of the communities we studied, helping to reduce uncertainty and at least partially mitigating concerns about over-adaptation," and that "experiencing current problems that communities associate with SLR has motivated many to act." $I d$. at 327-28. They note that their results "suggest that experience with current impacts of SLR can heighten awareness, increase 
Butler et al. also offer findings concerning the types of actions that communities are undertaking, notably that the primary focus to date has been on risk reduction rather than risk elimination. As they explain:

[O]ur research demonstrates behavior consistent with that reported in the natural hazard mitigation literature: communities are likely to continue to follow incremental low-regrets strategies until significant catastrophes arise that raise the salience of climate change induced hazards. Even then ... communities will most likely eschew the higher political and financial costs of risk elimination through avoidance and retreat, favoring instead conventional risk reduction strategies of accommodation and protection. ${ }^{224}$

Their sense of three aspects of what the future holds follows from their take on past experience. First, local governments are likely to be increasingly motivated to act as their constituents perceive that there are hazard impacts that are attributable to SLR and as they become more informed with "credible scientific knowledge" that reduces the "range of uncertainty" about the timing and degree of SLR. ${ }^{225}$ Second, local governments will need to become increasingly sophisticated in planning in order to "assess an array of plausible futures as they evaluate alternative adaptation strategies." 226 And, third, local governments will give increasing importance to both monitoring the "latest observations and predictions of SLR," and "evaluating the effectiveness of the incremental adaptation initiatives they have undertaken." ${ }^{227}$ It will be worthwhile to assess not only whether Butler et al. are correct in their speculation about future directions, but also the role of each of the innovations in Florida law and institutional structures

hazard salience, and build a sense of urgency." Id. at 328. They conclude that their "research demonstrates behavior consistent with that reported in the natural hazard mitigation literature: communities are likely to continue to follow incremental low-regrets strategies until significant catastrophes arise that raise the salience of climate change induced hazards." Id. at 329.

224. Id. (observing that " $[\mathrm{t}]$ his approach suggests that in many respects climate change adaptation planning behavior is nothing new," and that "[a] focus on risk reduction rather than risk elimination and taking incremental approaches to protection and accommodation have characterized flood hazard mitigation for decades").

225. Id. at 329-30. The adaptive governance literature appears to be consistent with this assessment. See Chaffin et al., supra note 8.

226. Butler et al., supra note 3 , at 330 .

227. Id. 
discussed in this paper (as well as others not discussed here), in influencing or shaping future efforts in each of these arenas.

\section{CONCLUSION}

Governing in dynamic times poses special challenges. ${ }^{228}$ Governance challenges in the context of a no-analog future, potentially presented by accelerating SLR and other impacts of climate change, raise the stakes even more. ${ }^{229}$ Florida, as is the case in much of the rest of the world, remains in the early stages of grappling with the challenges of adapting, and building resilience, to SLR and other impacts of climate change. ${ }^{230}$ In part, this is because adaptation traditionally was treated as the "neglected stepsister" in discussions about SLR and other impacts of climate change, with mitigation being the centerpiece of most. deliberations. ${ }^{231}$

Walker et al. point out that "[a]daptive management, widely and deservedly promoted as a necessary basis for sustainable development, has frequently failed because the existing governance structures have not allowed it to function effectively."232 Butler et al. among others, have identified significant barriers to effective adaptive management. These include "lack of funding, staff capacity, or other resources; fragmentation and lack of coordination among decision makers; institutional constraints such as lack of a mandate or restrictive management procedures; lack of leadership and polarization; and divergent perceptions of risk, culture, and values." ${ }^{233}$

228. Markell \& Glicksman, supra note 8 .

229. See Ruhl, supra note 120 , at 11 .

230. See RUPPERT \& STEWART, supra note 3; Carlson, supra note 8, at 1138-39 (discussing the early stage of efforts in the state of California, a state leader on environmental issues); supra notes 8-11.

231. Edna Sussman et al., Climate Change Adaptation: Fostering Progress through Law and Regulation, 18 N.Y.U. ENVTL. L.J. 55, 57 (2010); Ruhl, supra note 10, at 365-66, 372 (asserting that "the policy world's fixation on ... climate change mitigation has contributed to our neglect of national policy for climate change adaptation," and suggesting that the historic lack of attention has "stunted progress" in pursuing adaptation and has contributed to an "adaptation deficit" compared to other nations (citations omitted)); Ruhl \& Salzman, supra note 12 , at 979 .

232. Walker et al, supra note 207, at 7-8 (citations omitted).

233. Butler et al., supra note 3 , at 323 (citations omitted); see also CARMIN ET AL., supra note 12, at 2 (identifying as the "three top-ranked challenges" for cities as they pursue adaptation planning: (1) securing funding, (2) "communicating the need for adaptation," 
Butler et al. also offer some cause for optimism, as well as additional grounds for caution. They suggest that SLR "is one of the climate change impacts most amenable to adaptation planning because we understand the basics of the underlying mechanics, recognize that sea level change will be unfolding for centuries, and are well equipped to mitigate related impacts." ${ }^{234}$ They further note that " $[\mathrm{m}]$ ost of the impacts are familiar coastal hazards: SLR exacerbates coastal erosion, saltwater intrusion into coastal aquifers and surface waters, inundation of coastal lands, and storm surge flooding during coastal storms." ${ }^{235}$ But they caution that, because "the rate of sea level change appears to be accelerating[,] ... choosing what to do, where, and when as SLR unfolds requires contending with greater complexity and uncertainty and poses economic, environmental, and political risks." 236

The challenge of understanding vulnerability to SLR and related phenomena, and evaluating and implementing adaptation strategies in an iterative or adaptive way, is enormous in scope and multi-faceted. This review offers a close-up assessment of recent initiatives in Florida in an effort to inform and thereby contribute to filling the enormous extant knowledge deficit concerning adaptation initiatives. ${ }^{237}$ The Article also highlights the importance of close attention to key contextual features of effective governance, especially the legal regimes, institutional structures, and governance strategies that provide the backdrop for action. These aspects of governance provide important frames for contextualizing the challenges and the options for meeting them. ${ }^{238}$

and (3) "gaining commitment and generating appreciation from national government for the realities of local adaptation challenges"); id. at 20-24 (describing the various challenges in adaptation planning); SURVEY REPORT, supra note 3, at 16-17 (finding that municipalities identified funding and technical assistance as two forms of assistance that would be helpful). The need to establish metrics to evaluate performance, beyond simply cataloguing activity and including outcomes, is part of the challenge as well. See supra note 214.

234. Butler et al., supra note 3 , at 319 (citations omitted).

235. Id. (citations omitted).

236. Id. (citations omitted).

237. RUPPER'T \& STEWART, supra note 3 (reviewing local government efforts in Florida); see also supra note 214 and accompanying text.

238. For a forthcoming effort to evaluate the role of law in the development of different forms of governance, including adaptive governance, more generally, see Cosens et al., supra note 208 (discussing a project intended to "align ... adjustments in the legal framework for environmental management with the understanding of a specific ecological system and the goals of its society"). One example of the importance of considering the full range of 
[Vol. 42:1

potential actors, which this Article does not discuss and which is likely to attract more attention in the future, involves local governments' possible legal exposure for their actions or inactions in connection with SLR-related issues. See Thomas Ruppert \& Carly Grimm, Drowning in Place: Local Government Cosls and Liabilities for Flooding Due to Sea-Level Rise, 87 FLA. BAR J. 29, 31-32 (2013); Wilkins, supra note 107, at 483. 